\title{
Identification and taxonomy of Betula (Betulaceae) in Great Britain and Ireland
}

\author{
Andy Amphlett \\ Grantown on Spey, Scotland
}

\section{Corresponding author: amphlett1958@gmail.com}

This pdf constitutes the Version of Record published on $26^{\text {th }}$ July 2021

\begin{abstract}
Floras and identification guides typically do not list the full range of identification features that discriminate between Betula pendula Roth and B. pubescens Ehrh., and some accounts contain errors. Discriminatory identification features are described and illustrated. Introgression from the diploid, $B$. pendula into $B$. pubescens is widespread. It also occurs from $B$. nana $\mathrm{L}$. into $B$. pubescens, but obviously introgressed examples of the latter are probably rare. Betula pubescens presents the greatest unresolved identification difficulties. Trees identified as $B$. pubescens subsp. celtiberica (Rothm. \& Vasc.) Rivas Mart., particularly in Wales, may be part of the variation within British $B$. pubescens, due to introgression from B. pendula. The most widespread of the small-leaved forms of $B$. pubescens is correctly named var. fragrans Ashburner \& McAll. Several misapplied names have been given to this taxon, most recently subsp. tortuosa (Ledeb.) Nyman, which does not occur in Europe. Not all small-leaved B. pubescens are var. fragrans, some examples show clear signs of introgression from $B$. nana, and may be referable to the northern var. pumila (L.) Govaerts.
\end{abstract}

Keywords: introgression; ploidy level; hybridisation

\section{Introduction}

The taxonomy and naming of Birch (Betula) has been the source of confusion and dispute ever since Linnaeus published his Species Plantarum in 1753. Linnaeus's Betula alba L. is now accepted as comprising two species, $B$. pendula Roth (Silver Birch) and B. pubescens Ehrh. (Downy Birch). A third species Betula nana L. (Dwarf Birch) is distinctive, and taxonomically uncontroversial.

In combination, $B$. pendula and $B$. pubescens are almost ubiquitous at hectad scale in Great Britain and Ireland. However their frequency relative to each other varies markedly (Fig. 1). B. pubescens is the more frequent species across almost all of Ireland, Scotland (except the east), Wales, north-west and parts of southwest England. B. pendula is the more frequent species in north-east, central and southern England, and in east and north-east Scotland. It is likely that distribution maps for these two species contain some errors (e.g. Worrell \& Malcolm, 1998). 


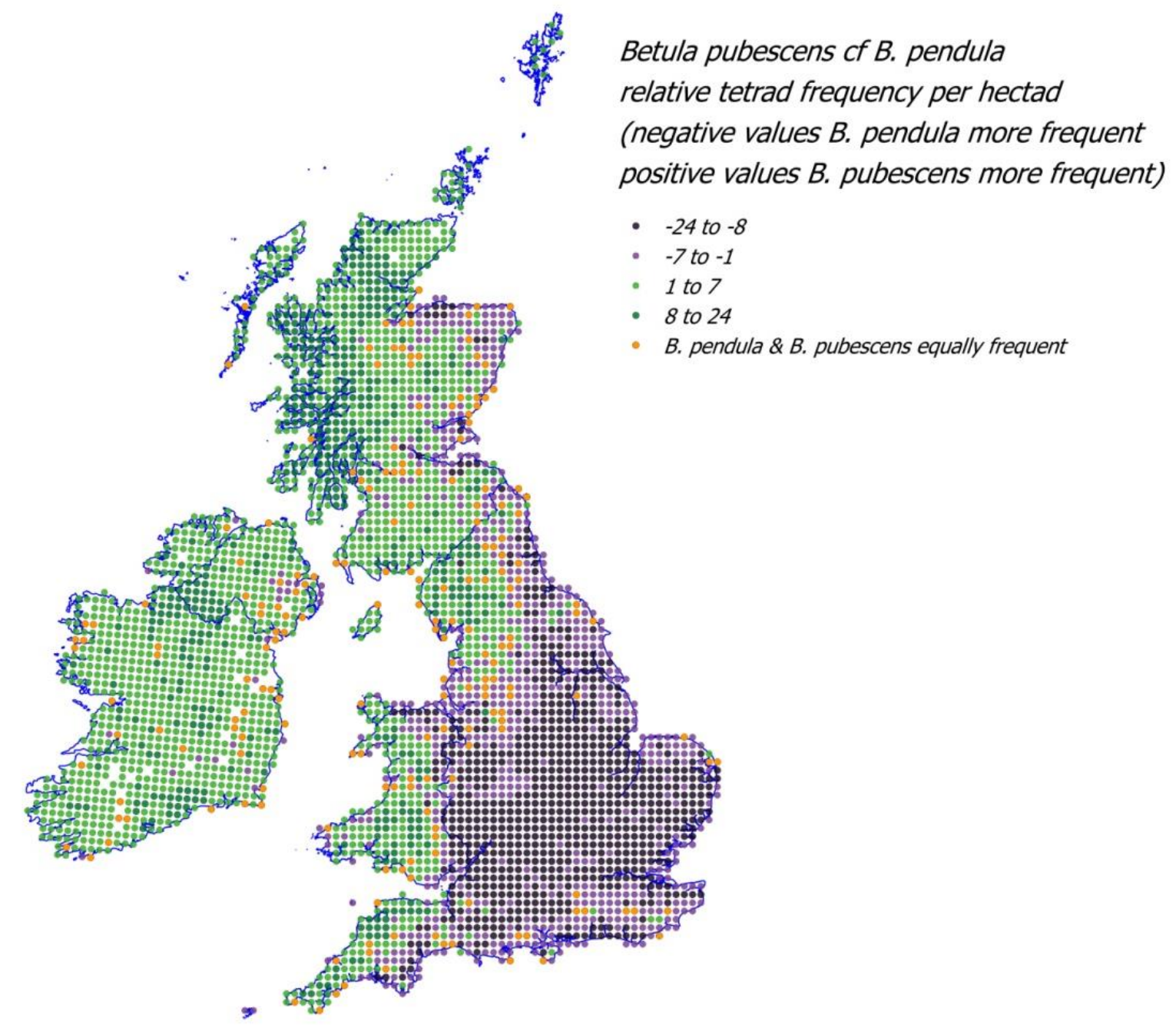

Figure 1. Relative tetrad frequency per hectad of Betula pubescens and $B$. pendula in Great Britain and Ireland (From BSBI Distribution Database, https://database.bsbi.org $/$, accessed February 2021)

Problems relating to the identification of British and Irish Betula are due to:

1) Identification features of $B$. pendula and $B$. pubescens being poorly and incompletely described in some popular Floras and Field Guides.

2) The occurrence of the $\mathrm{F} 1$ hybrid between $B$. pendula and B. pubescens, Betula $X$ aurata (Borkh.).

3) Introgression from the diploid $(2 \mathrm{n}=28) B$. pendula and $B$. nana, into the tetraploid $(2 \mathrm{n}=56)$ B. pubescens.

4) The occurrence of distinctive local forms, especially of $B$. pubescens.

5) Planting of alien (to the local area) genotypes and species, and effects of habitat disturbance.

6) Misapplication of names to taxa within B. pubescens.

7) Misleading interpretations of the relationship between the small-leaved $B$. pubescens in the Highlands of Scotland and Scandinavian and Icelandic 'mountain birch'.

These issues are discussed in turn below. 
1) Identification features of $B$. pendula vs. $B$. pubescens and of $B$. nana. Commonly used Floras and identification guides typically do not list the full range of identification features that discriminate between B. pendula and B. pubescens, and some accounts contain errors. Examining a classic example of the small-leaved $B$. pubescens subsp. tortuosa (sensu Stace, 2019) in the Highlands of Scotland, a botanist using one of the two popular Field Guides (Rose, 2006; Streeter, 2009) might well be stumped as to what they were looking at. Given that such trees may have whitish bark, pendulous and glabrous fine twigs, that may have frequent glands (or warts), and leaves that may be almost glabrous later in the summer, they may well decide they are looking at a form of $B$. pendula. The latest edition of the New Flora of the British Isles (Stace, 2019), has some significant errors in the keys, text and illustrations. The key to species in Stace (2019) does satisfactorily distinguish between B. pendula and B. pubescens. However, the drawing of the fruiting bract of $B$. pendula does not show the diagnostic shape and the drawing of the fruiting bract of $B$. pubescens is wrong; the fruiting bracts are said to have lateral lobes "directed laterally or slightly backwards" whereas they point forwards (unless introgressed), which is a key difference from $B$. pendula. The leaves of subsp. tortuosa (sensu Stace, 2019) are not conspicuously hairy as stated in the key to subspecies, and the shoots frequently have many (not few) sessile glands. It is described as usually shrubby, but is almost always a tree. Of easily accessed identification guides, the account in Plant Crib (Rich \& Jermy, 1998, and available online) is reliable. For discussion of B. pubescens subsp. celtiberica see Section 4, below.

The Atkinson discriminant function (ADF) (Atkinson \& Codling, 1986) is a recommended tool to distinguish between $B$. pendula and $B$. pubescens using three leaf characters; details are given in Stace (2019). The function was based on a sample of 104 trees in 14 self-sown populations in England and Scotland. The discriminatory power of the function has recently been tested on a much larger dataset (Wang et al., 2014b). They calculated the ADF for 944 Betula trees (780 B. pubescens and 164 B. pendula) from 105 populations. The species identifications had previously been determined using 12 microsatellite loci (Wang et al, 2014a). Using an ADF value of zero as the boundary between the two species, as originally proposed, the ADF value correctly identified $96.4 \%$ of samples. Using a boundary value of -2 raised the success rate to $97.5 \%$. However, between ADF values of -11 to +3 , error rates exceeded $10 \%$. (Fig. 2 ).

The practical usefulness of the ADF seems to be limited. It reliably distinguishes between the two species in cases where leaf shape is fairly obviously one or other species. When it would be most useful is when their leaf shapes are most similar. Here the error rate increases to over $10 \%$. Some of the trees sampled by Wang et al. (2014b) showed evidence of introgression, but they concluded that the morphological continuum between the leaf shapes of the two species "is inherent to the species, and hybridisation is not its major cause". 


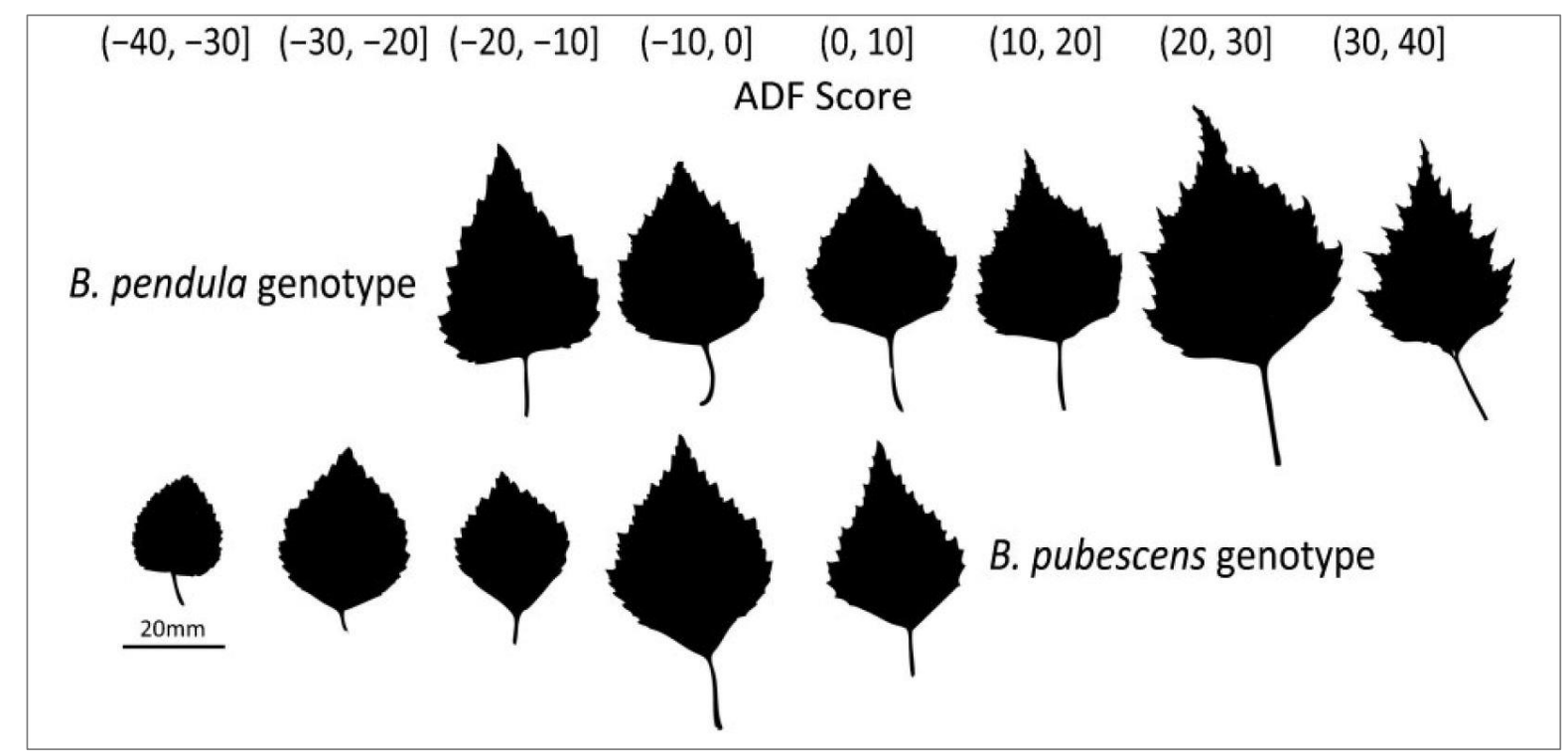

Figure 2. Representative leaf shapes of Betula pendula and B. pubescens (determined by microsatellite data) for different Atkinson discriminant function scores (from Wang et al, 2014b)

Betula nana (Fig. 3) is a highly distinctive shrub, prostrate or erect (maximum height $c .1$ metre), with small, shining, dark green, subcoriaceous, rounded leaves with crenate teeth (teeth not acute and triangular as in the other species and hybrids), and densely 'furry' hairy shoots. It has a totally different arrangement of catkins with overwintering male catkins never terminal, but lateral, usually below females, and over winter looking like elongated buds, and erect fruiting catkins. Its hybrid with $B$. pubescens, $B . x$ intermedia (Fig. 27) is little known to British botanists, having only been recorded by $c .12$ recorders since 1987 . B. nana, recorded from 101 hectads post 1999, is almost restricted to the Scottish Highlands; it is rare in northern England. The hybrid is recorded from 10 hectads post 1999, and was reported from Northumberland in 2020, new to England. (Hectad counts from BSBI Distribution Database, March 2021).

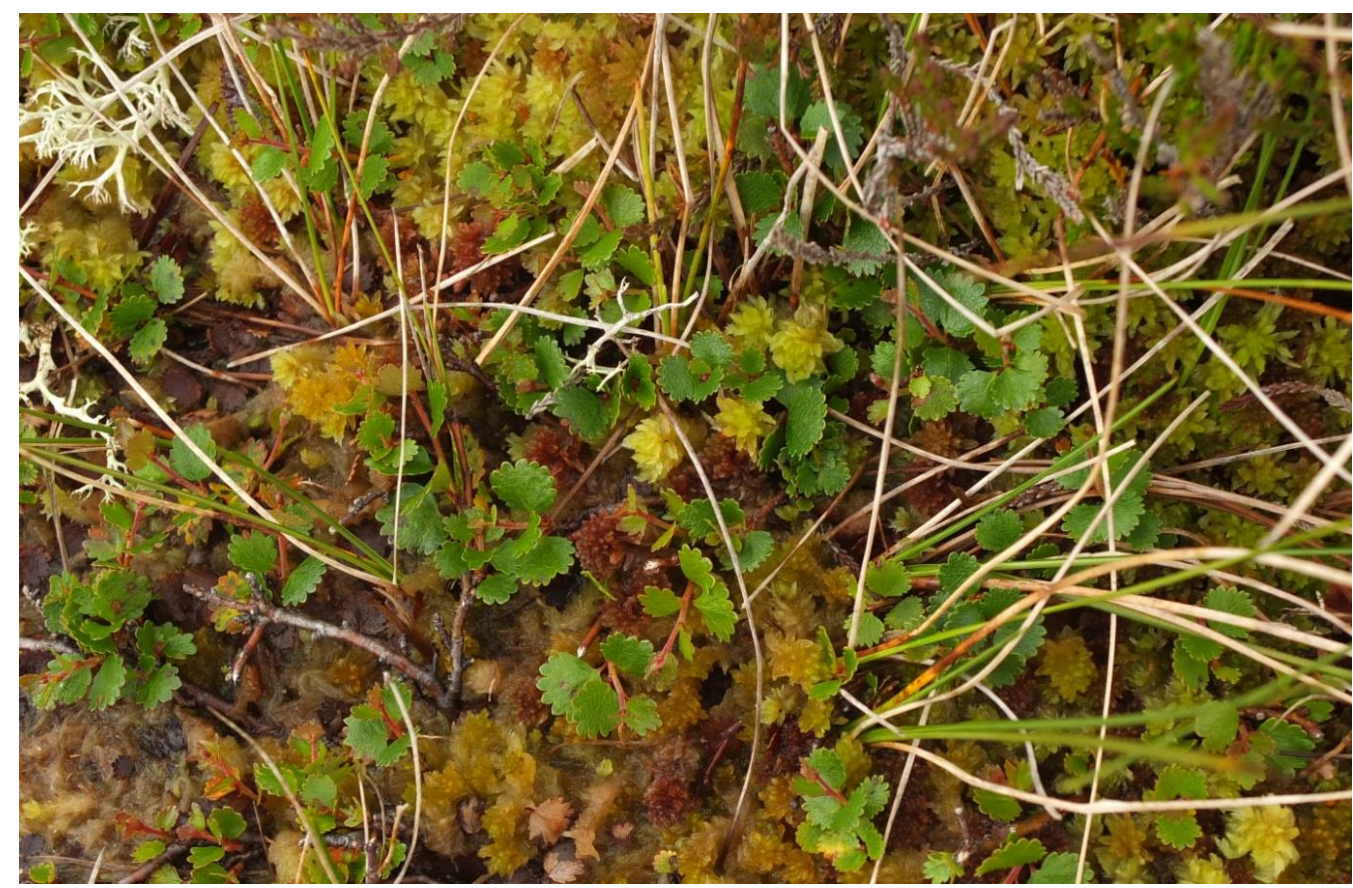

Figure 3. Betula nana 
Identification features of $B$. pendula and B. pubescens are given in Table 1. Identifications should always be based on consideration of as many features as possible. I have drawn on a wide range of literature and personal experience in the field (mainly in north Scotland) when compiling this. Note that the name $B$. pubescens var. fragrans (Ashburner \& McAllister) is used in place of $B$. pubescens subsp. tortuosa (sensu Stace, 2019); see Section 6 for discussion.

Table 1. Identification features of Betula pendula and B. pubescens

\begin{tabular}{|c|c|c|c|}
\hline & B. pendula & $\begin{array}{l}\text { B. pubescens } \\
\text { subsp. } \\
\text { pubescens }\end{array}$ & $\begin{array}{l}\text { B. pubescens } \\
\text { var. fragrans* }\end{array}$ \\
\hline Tree form / Habit & \multicolumn{2}{|c|}{$\begin{array}{l}\text { Tall trees, usually with a single trunk, } \\
\text { extending into the canopy. }\end{array}$} & $\begin{array}{l}\text { Except in very } \\
\text { exposed or high } \\
\text { altitude locations, } \\
\text { forms a low }(5 \mathrm{~m}) \\
\text { to medium height } \\
\text { tree, exceptionally } \\
\text { to } 12-15 \mathrm{~m} \text {. Trunk } \\
\text { short, not usually } \\
\text { extending into the } \\
\text { canopy. Often } \\
\text { multi-stemmed } \\
\text { from, or near to, } \\
\text { the base. }\end{array}$ \\
\hline Branches & $\begin{array}{l}\text { Ascending, with } \\
\text { fine twigs and } \\
\text { branchlets often } \\
\text { (but not always) } \\
\text { pendulous. Classic } \\
\text { trees have all } \\
\text { branches showing } \\
\text { this pendulous } \\
\text { character. Planted } \\
\text { trees are } \\
\text { sometimes } \\
\text { exaggeratedly and } \\
\text { atypically } \\
\text { pendulous, eg } C V \text {. } \\
\text { tristis. Some wild } \\
\text { trees are hardly } \\
\text { pendulous, and } \\
\text { young trees do } \\
\text { not display this } \\
\text { trait. Beware } \\
\text { markedly } \\
\text { pendulous forms } \\
\text { of } B \text {. pubescens } \\
\text { var. fragrans }\end{array}$ & $\begin{array}{l}\text { Ascending. Fine } \\
\text { twigs and } \\
\text { branchlets never } \\
\text { pendulous. }\end{array}$ & $\begin{array}{l}\text { Trees of great } \\
\text { individual } \\
\text { character. } \\
\text { Branches variably } \\
\text { twisting or } \\
\text { contorted, } \\
\text { creating intricate } \\
\text { branching } \\
\text { patterns. On most } \\
\text { trees, fine twigs of } \\
\text { lower branches } \\
\text { somewhat to } \\
\text { markedly } \\
\text { pendulous. Fine } \\
\text { twigs of upper } \\
\text { branches typically } \\
\text { spreading in all } \\
\text { directions, and not } \\
\text { pendulous. Some } \\
\text { trees hardly } \\
\text { display this } \\
\text { pendulous } \\
\text { character, while } \\
\text { occasional trees }\end{array}$ \\
\hline
\end{tabular}




\begin{tabular}{|c|c|c|c|}
\hline & $\begin{array}{l}\text { which can look } \\
\text { similar at a } \\
\text { distance. }\end{array}$ & & $\begin{array}{l}\text { have pendulous } \\
\text { fine twigs on all } \\
\text { branches. }\end{array}$ \\
\hline Bark of trunk & $\begin{array}{l}\text { Upper trunk } \\
\text { white, mid and } \\
\text { lower parts with } \\
\text { vertical splits or } \\
\text { gashes, } \\
\text { sometimes } \\
\text { diamond-shaped. } \\
\text { Bark thinly } \\
\text { peeling. Black } \\
\text { inverted V marks } \\
\text { above branch / } \\
\text { trunk junctions. } \\
\text { Base of trunk } \\
\text { often with no } \\
\text { white bark, } \\
\text { broken up into } \\
\text { very rough dark, } \\
\text { cubic or } \\
\text { rectangular hard } \\
\text { corky bosses. }\end{array}$ & \multicolumn{2}{|c|}{$\begin{array}{l}\text { Trunk typically white or grey-white, } \\
\text { sometimes brown. Never with vertical } \\
\text { splits or gashes. Base of trunk same } \\
\text { colour as upper, never broken up into } \\
\text { very rough dark bosses, often fluted. } \\
\text { Bark may partially break up into curls. } \\
\text { Horizontal lenticels creating obvious } \\
\text { parallel lines. (Bark of var. fragrans in } \\
\text { the Highlands, often largely obscured by } \\
\text { lichens, bryophytes and algae, masking } \\
\text { the actual colour). }\end{array}$} \\
\hline $\begin{array}{l}\text { Young twigs } \\
\text { (preceding year, } \\
\text { and current year } \\
\text { late in summer) }\end{array}$ & $\begin{array}{l}\text { Thin. Glabrous, } \\
\text { (never } \\
\text { puberulent**), } \\
\text { with round, pale, } \\
\text { glands / warts in } \\
\text { addition to oval } \\
\text { lenticels. Glands } \\
\text { are most } \\
\text { abundant on } \\
\text { vigorous shoots } \\
\text { eg. of young } \\
\text { trees. Twigs on } \\
\text { old trees may } \pm \\
\text { lack glands. Twigs } \\
\text { are sometimes } \\
\text { covered by a } \\
\text { greyish, peeling } \\
\text { epidermis. }\end{array}$ & $\begin{array}{l}\text { Usually pubescent } \\
\text { (hairs visible to } \\
\text { naked eye) and / } \\
\text { or puberulent (use } \\
\text { lens). Glands } \\
\text { often described as } \\
\text { absent, but may } \\
\text { be sparse or } \\
\text { frequent, with } \\
\text { oval lenticels. }\end{array}$ & $\begin{array}{l}\text { Thin; may be as } \\
\text { thin as } B \text {. } \\
\text { pendula. Glabrous } \\
\text { or puberulent (use } \\
\text { lens), with or } \\
\text { without longer } \\
\text { hairs, with } \\
\text { resinous smelling, } \\
\text { brown glands and } \\
\text { oval lenticels. }\end{array}$ \\
\hline Buds & $\begin{array}{l}\text { Often more } \\
\text { pointed than } B \text {. } \\
\text { pubescens. }\end{array}$ & $\begin{array}{l}\text { Usually not viscid, } \\
\text { without resinous } \\
\text { smell in spring. }\end{array}$ & $\begin{array}{l}\text { Viscid. Resinous } \\
\text { smell in spring. }\end{array}$ \\
\hline $\begin{array}{l}\text { Leaves (on short } \\
\text { shoots, and pre- } \\
\text { formed leaves at } \\
\text { base of long } \\
\text { shoots). }\end{array}$ & $\begin{array}{l}\text { Acute to } \\
\text { acuminate at } \\
\text { apex, truncate to } \\
\text { cuneate at base. } \\
\text { Teeth double, }\end{array}$ & $\begin{array}{l}\text { Leaves }>(3) 3.5 \\
\text { cm length, } \\
\text { without obvious } \\
\text { primary teeth. } \\
\text { Rounded to }\end{array}$ & $\begin{array}{l}\text { Leaves } \leq 3(3.5) \\
\text { cm length, } \\
\text { frequently less } \\
\text { than } 3 \mathrm{~cm} \text {, without } \\
\text { obvious primary }\end{array}$ \\
\hline
\end{tabular}




\begin{tabular}{|c|c|c|c|}
\hline $\begin{array}{l}\text { Ignore other } \\
\text { leaves on long } \\
\text { shoots (they differ } \\
\text { in shape). } \\
\text { Epicormic, basal } \\
\text { or coppice shoots, } \\
\text { and seedlings are } \\
\text { usually hairy in } \\
\text { both species } \\
\text { (ignore). }\end{array}$ & $\begin{array}{l}\text { primary teeth } \\
\text { prominent, } \\
\text { attenuate, often } \\
\text { curving towards } \\
\text { leaf apex. } \\
\text { Glabrous. }\end{array}$ & $\begin{array}{l}\text { cuneate at base. } \\
\text { Usually hairy, at } \\
\text { least below. }\end{array}$ & $\begin{array}{l}\text { teeth. Rounded to } \\
\text { cuneate at base. } \\
\text { Apex usually } \\
>80^{\circ} \text {. Sparsely } \\
\text { hairy to glabrous. } \\
\text { Covered in } \\
\text { frequent small } \\
\text { brown glands. } \\
\text { Resinous smell in } \\
\text { spring. (If }<(20) \\
15 \mathrm{~mm} \text { length, } \\
\text { may be hybrids } \\
\text { with } B \text {. nana or } \\
\text { heavily } \\
\text { introgressed from } \\
B . \text { nana). }\end{array}$ \\
\hline Fruiting catkin & Pendent & \multicolumn{2}{|c|}{$\begin{array}{l}\text { Pendent. (If variably erect, may suggest } \\
\text { introgression from } B \text {. nana). }\end{array}$} \\
\hline $\begin{array}{l}\text { Fruiting scales / } \\
\text { bracts. Examine } \\
\text { from middle of } \\
\text { several mature } \\
\text { catkins. }\end{array}$ & $\begin{array}{l}\text { Lateral lobes } \\
\text { spreading, } \pm \\
\text { falcate and } \\
\text { sometimes } \\
\text { strongly so. Look } \\
\text { like a bird in } \\
\text { flight, eg a } \\
\text { Peregrine falcon, } \\
\text { or 'fleur de lys' } \\
\text { shaped. }\end{array}$ & \multicolumn{2}{|c|}{$\begin{array}{l}\text { Lateral lobes pointing forward at angle } \\
\text { of } c .45^{\circ} \text {. If spreading, with slight } \\
\text { tendency for rear edge to curve } \\
\text { backwards towards base of bract, may } \\
\text { indicate introgression from } B \text {. pendula. } \\
\text { If lateral lobes erect, or nearly so, } \\
\text { suggests introgression from } B \text {. nana. }\end{array}$} \\
\hline $\begin{array}{l}\text { Nutlets. Examine } \\
\text { from middle of } \\
\text { several mature } \\
\text { catkins. }\end{array}$ & $\begin{array}{l}\text { Glabrous. Narrow } \\
\text { cf. length. }\end{array}$ & \multicolumn{2}{|c|}{$\begin{array}{l}\text { Tuft of very short hairs at base of styles } \\
\text { (use lens } \times 20 \text { ). Relatively broad cf. } \\
\text { length. }\end{array}$} \\
\hline $\begin{array}{l}\text { Nutlet wing. } \\
\text { Examine from } \\
\text { middle of several } \\
\text { mature catkins. }\end{array}$ & $\begin{array}{l}\text { Each wing } 2-3 \\
\text { times width of } \\
\text { nutlet, typically } \\
\text { extending beyond } \\
\text { styles. }\end{array}$ & \multicolumn{2}{|c|}{$\begin{array}{l}\text { Each wing } 1(-2) \text { times width of nutlet, } \\
\text { typically not extending beyond styles. If } \\
\text { wing }<<\text { width of nutlet, may suggest } \\
\text { introgression from } B \text {. nana. }\end{array}$} \\
\hline
\end{tabular}

* B. pubescens subsp. tortuosa (sensu Stace)

**Puberulent refers to very short hairs, $0.03-0.3 \mathrm{~mm}$ in length, growing at rightangles to surfaces, e.g. of twigs. Hold specimen to the light and check with a hand lens for presence of hairs in silhouette. Such hairs are usually to be found on $B$. pubescens, and never on $B$. pendula. The shortest examples of these hairs can be easily missed with a cursory examination. Magnification of $>x 10$ is advised.

It should be noted that:

- B. pendula may have occasional long $(c .1 \mathrm{~mm})$ hairs on leaf margins, bud scales and young leaf veins. Seedling stems and leaves are hairy. 
- The characteristic 'fleur de lys' fruiting catkin scales of $B$. pendula with reflexed lateral lobes also occur in $B$. pubescens highly introgressed from $B$. pendula, in $B$. celtiberica and in some $B$. papyrifera Marshall.

In summary (and see Section 3 re. introgression), once the pure $B$. pendula and pure $B$. nana (both diploids) are known these can almost always be fairly easily distinguished from tetraploid $B$. pubescens. The latter may display evidence of variable amounts of introgression from one or other of these two species. In mixed stands of $B$. pendula and $B$. pubescens the important thing is to certainly identify $B$. pendula (if present); all the remaining birches are likely to be tetraploid and freely inter-fertile, and hence effectively comprising a breeding unit distinct from a 'pure' $B$. pendula breeding population. These tetraploids can be recorded as $B$. pubescens.

Many of the features listed in Table 1 are illustrated below: Betula pendula (Figs. 4 - 9; Betula pubescens subsp. pubescens (Figs. 10,11,21); Betula pubescens var. fragrans (Figs. 12-19,22); Betula pubescens s.l. (Fig. 20).

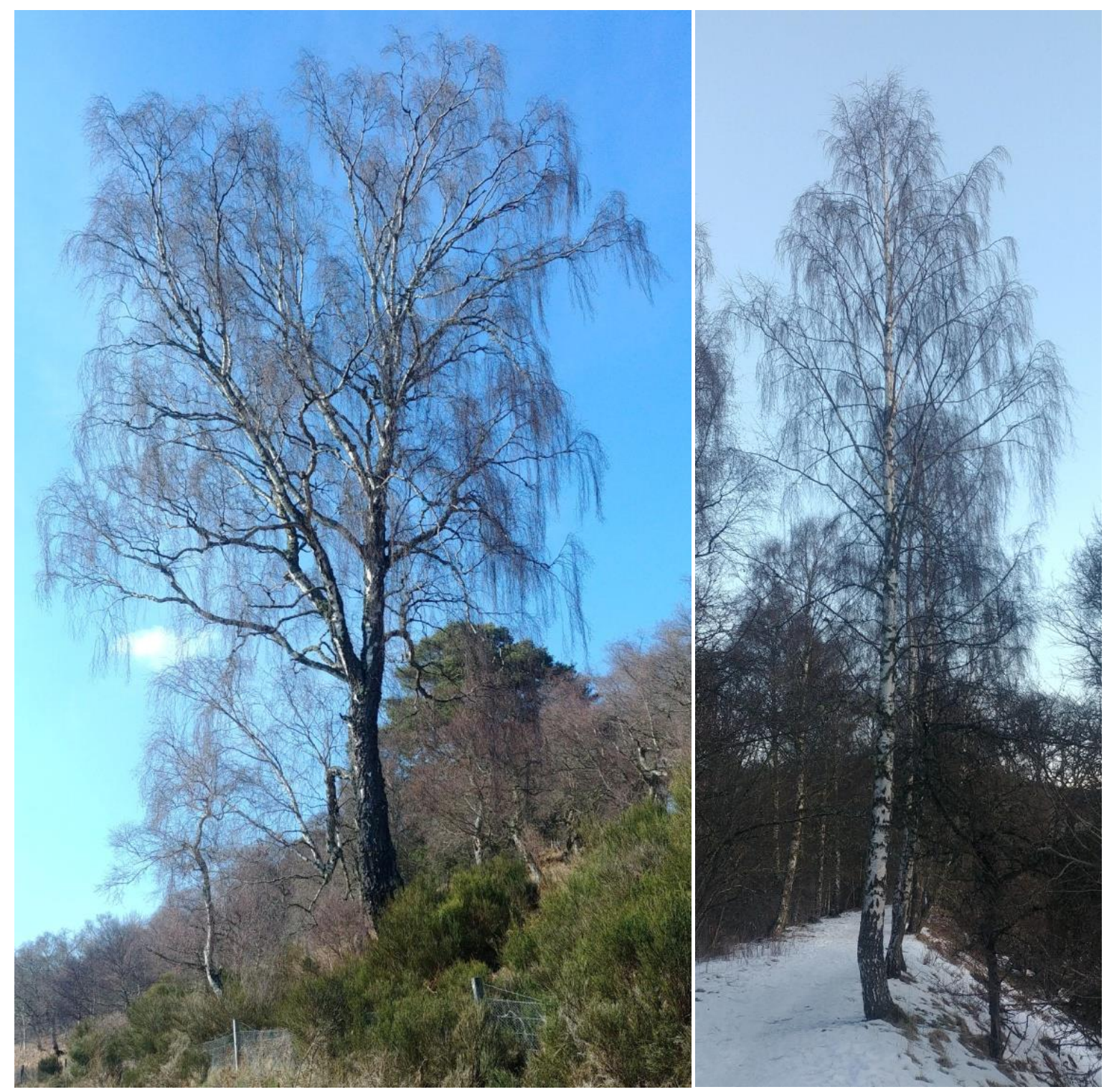

Figure 4. 'Classic' pendulous form of Betula pendula 


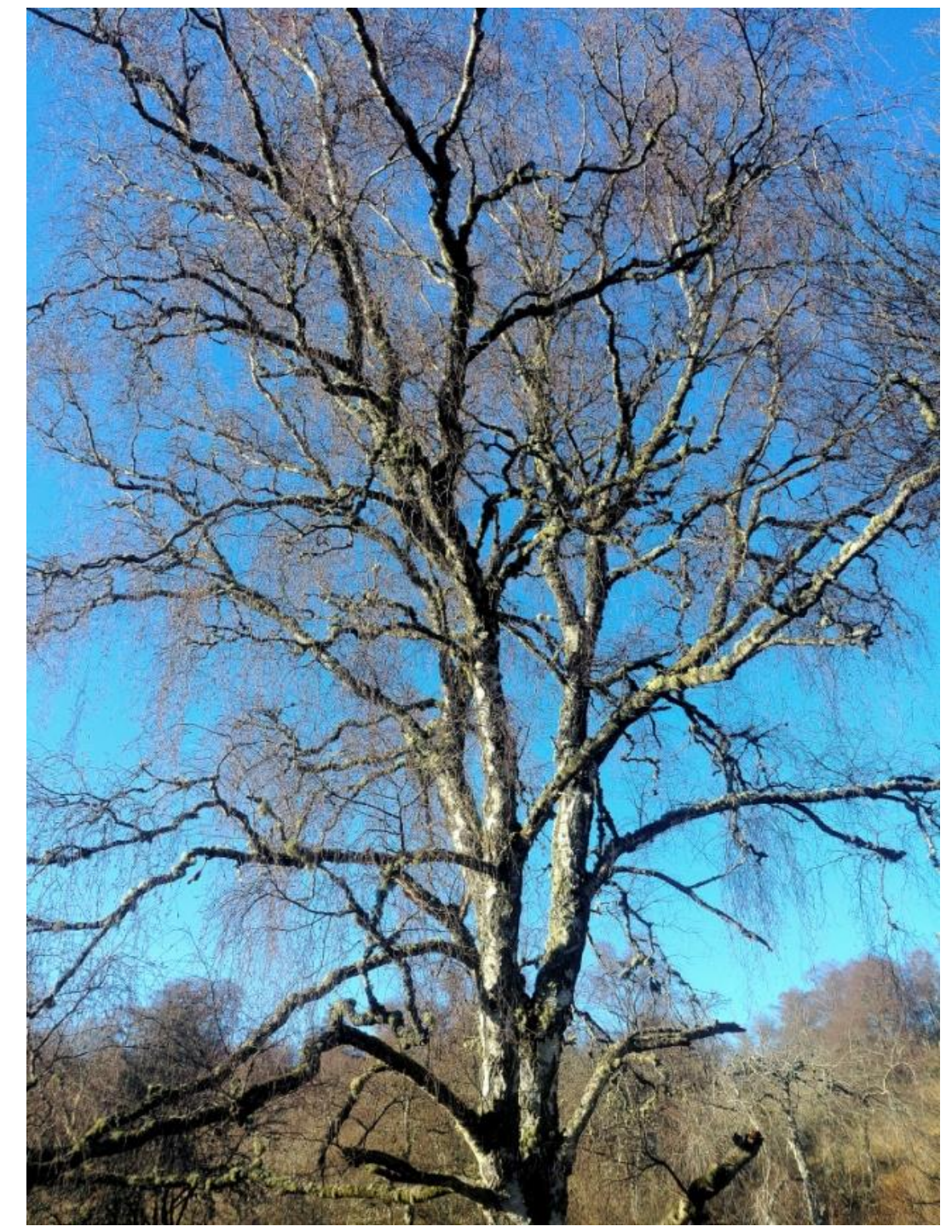

Figure 5. Old trees of Betula pendula can develop intricate, spreading branches

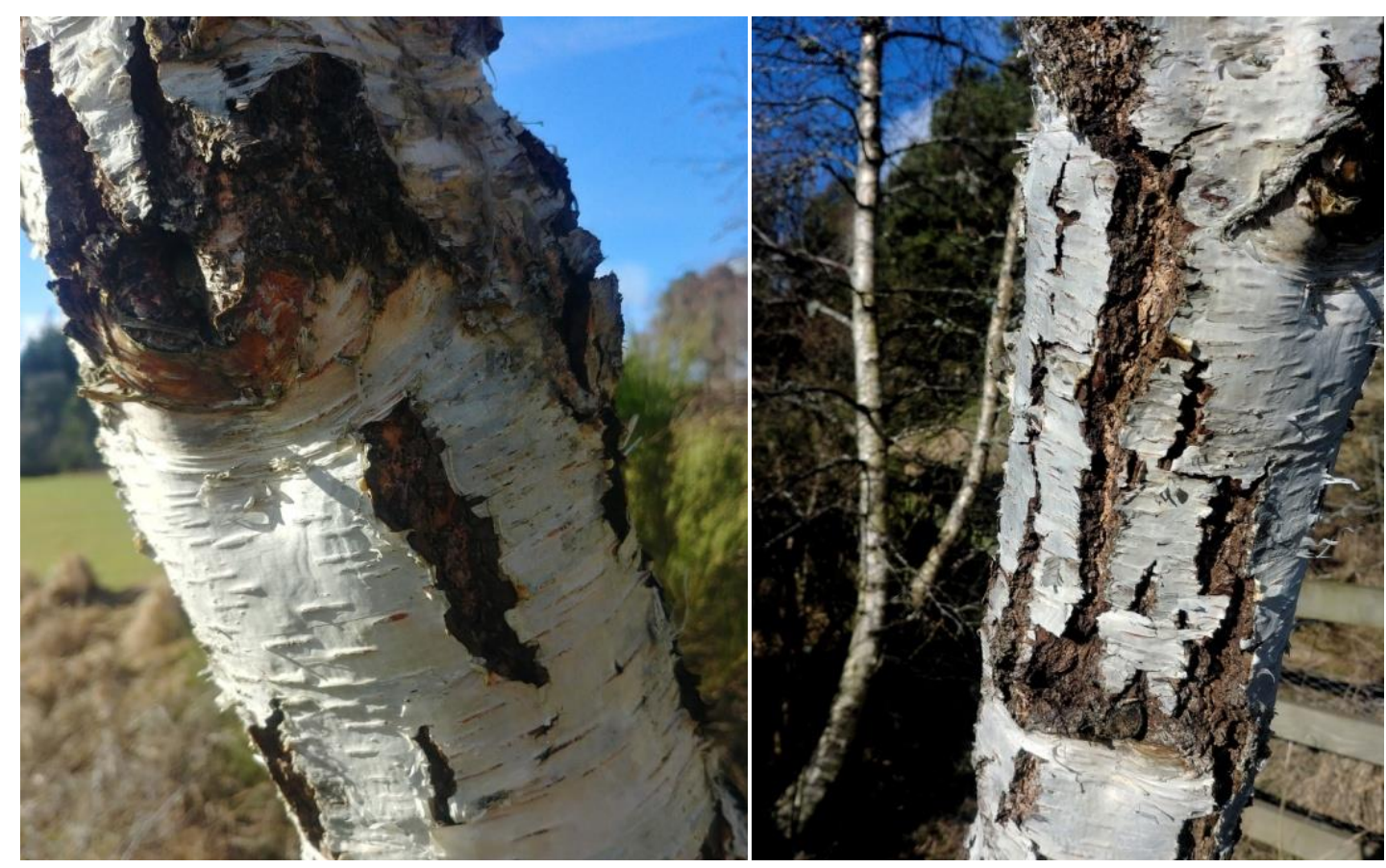

Figure 6. Betula pendula showing vertical splits in bark 


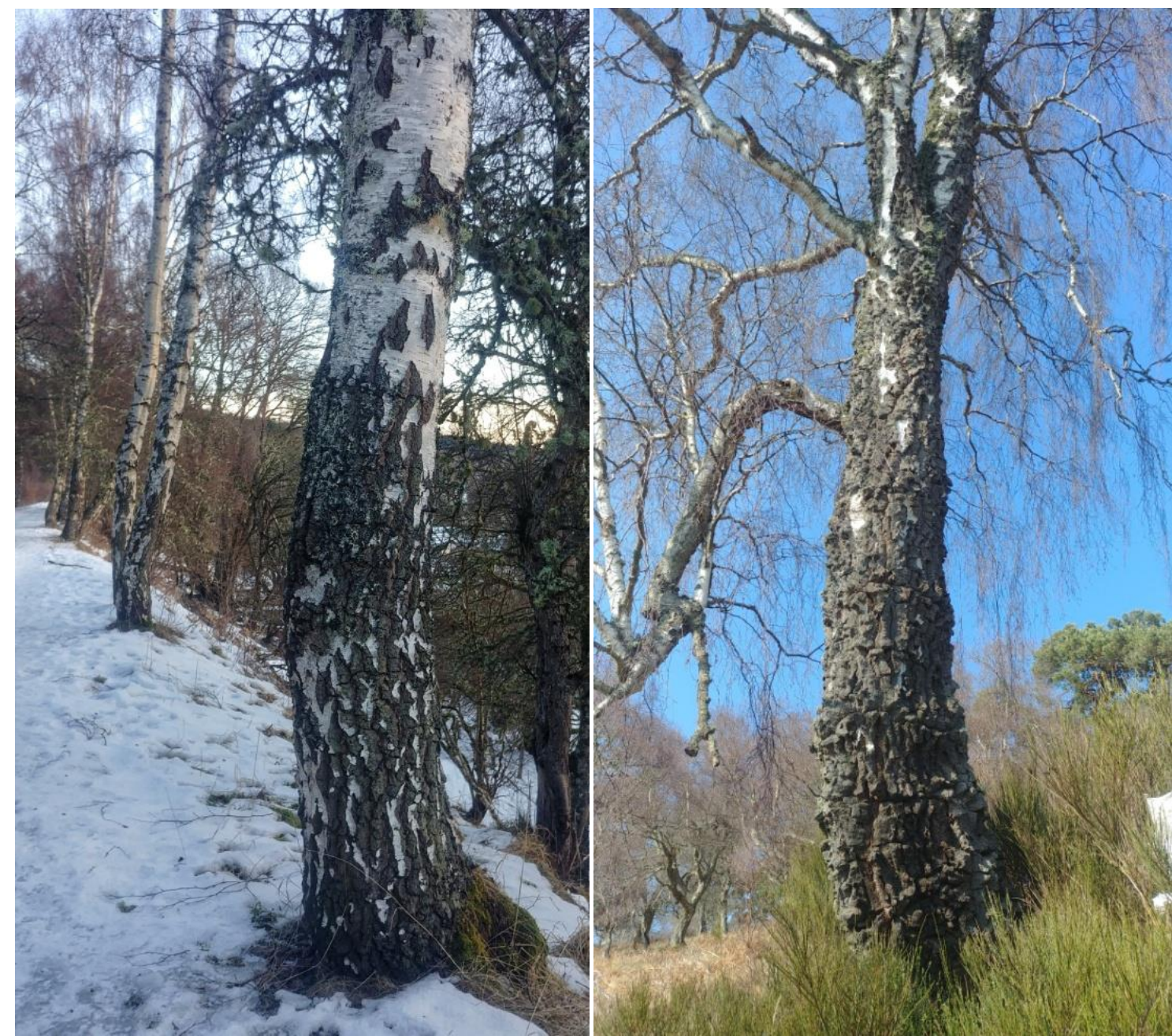

Figure 7. Betula pendula lower trunk. Left: transition from white bark (above) with vertical splits to increasingly rugged lower trunk. Right: exceptionally rugged trunk on an old tree.

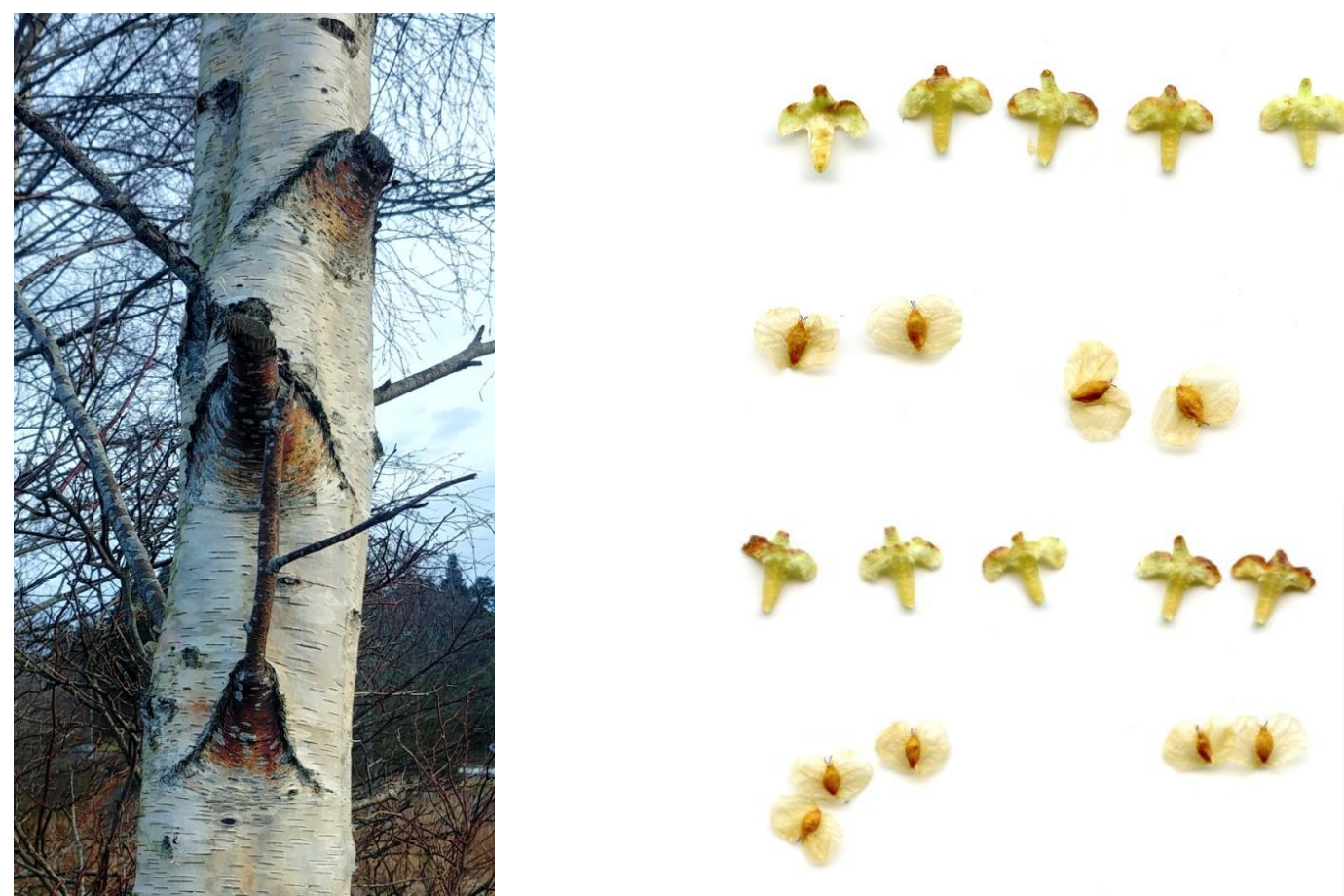

Figure 8. Betula pendula inverted dark V marks above branches (left), female catkin scales and fruits (right) 


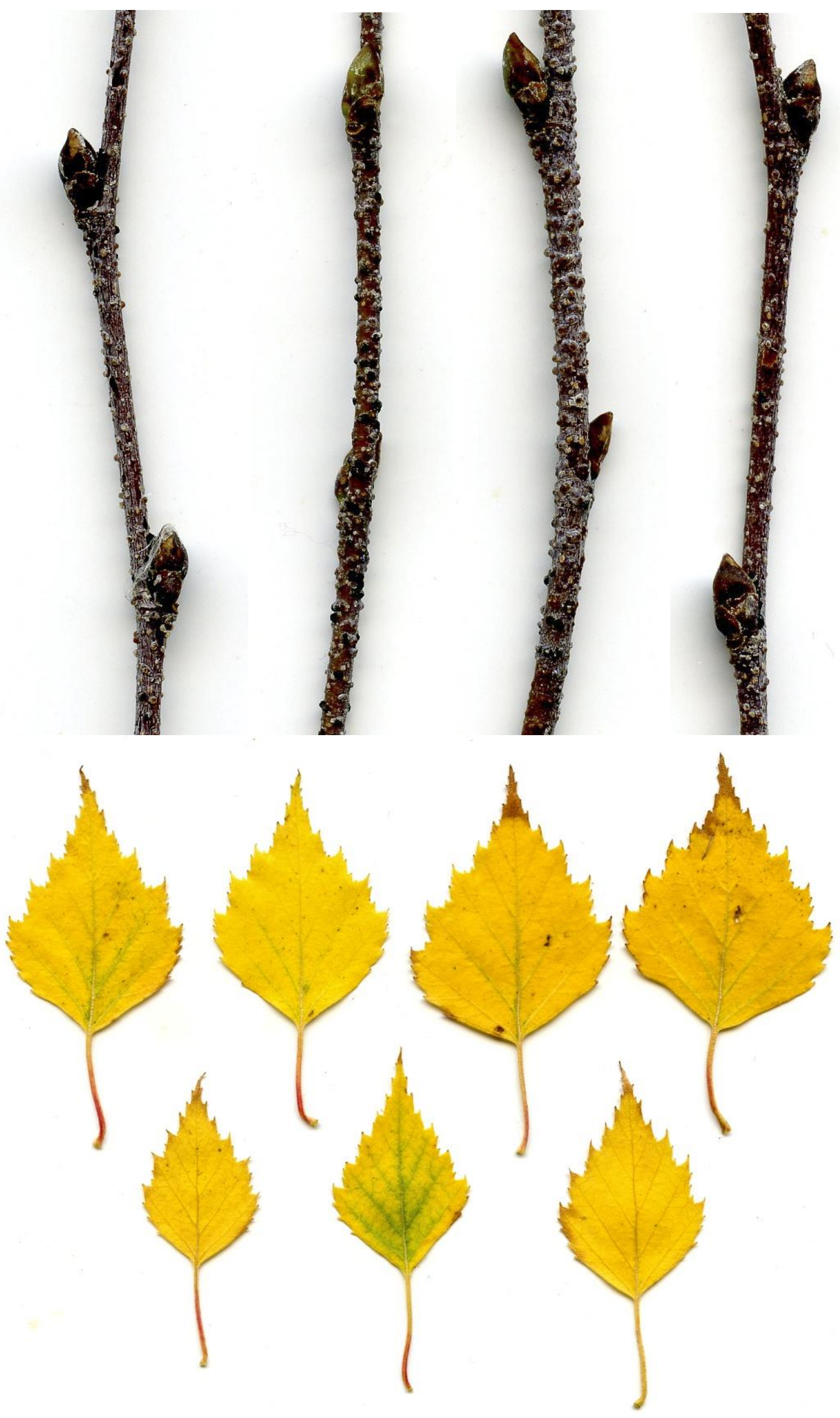

Figure 9. Betula pendula, twigs from vigorous saplings (top) Betula pendula leaves (below) 


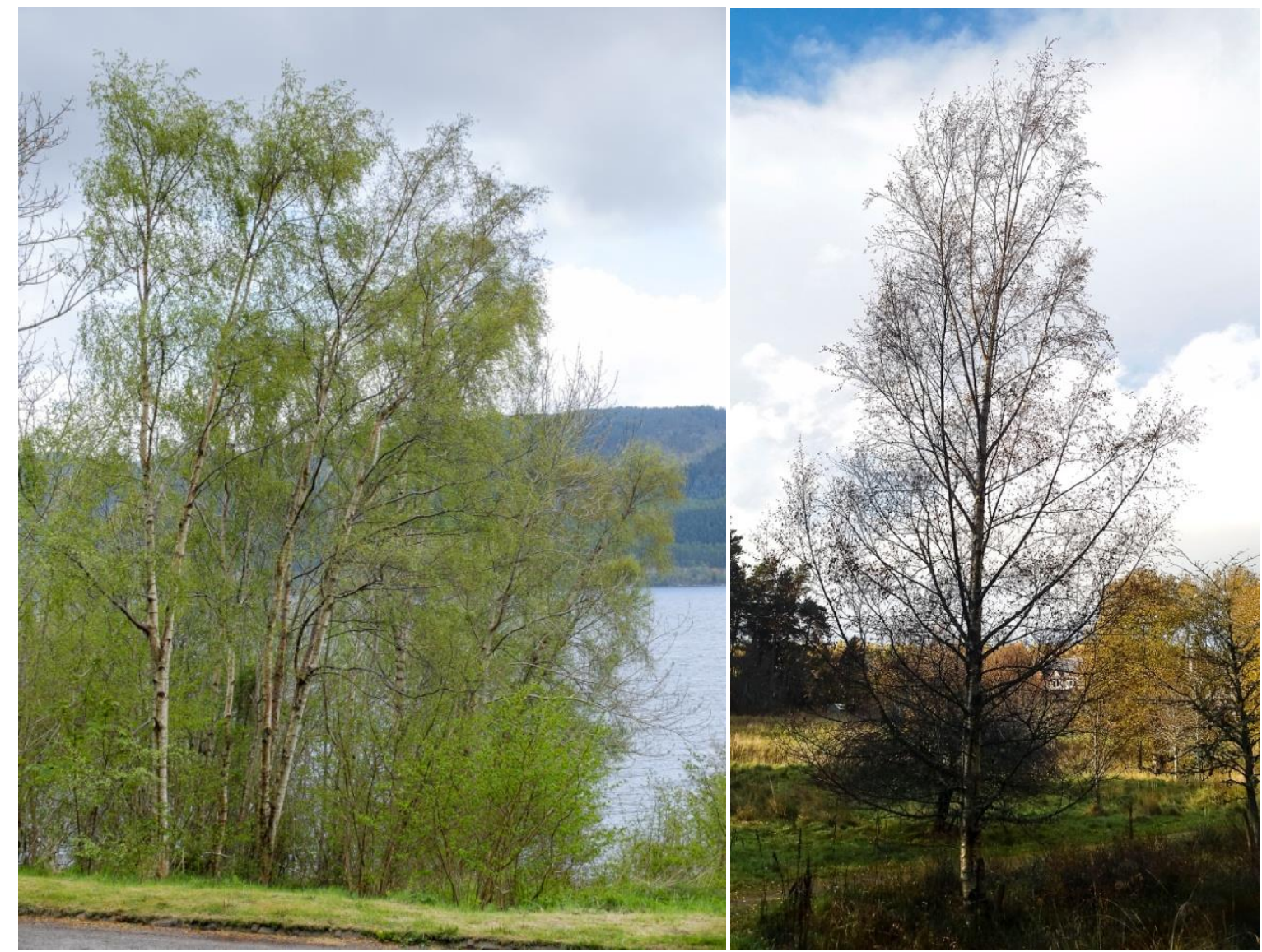

Figure 10. Betula pubescens subsp. pubescens

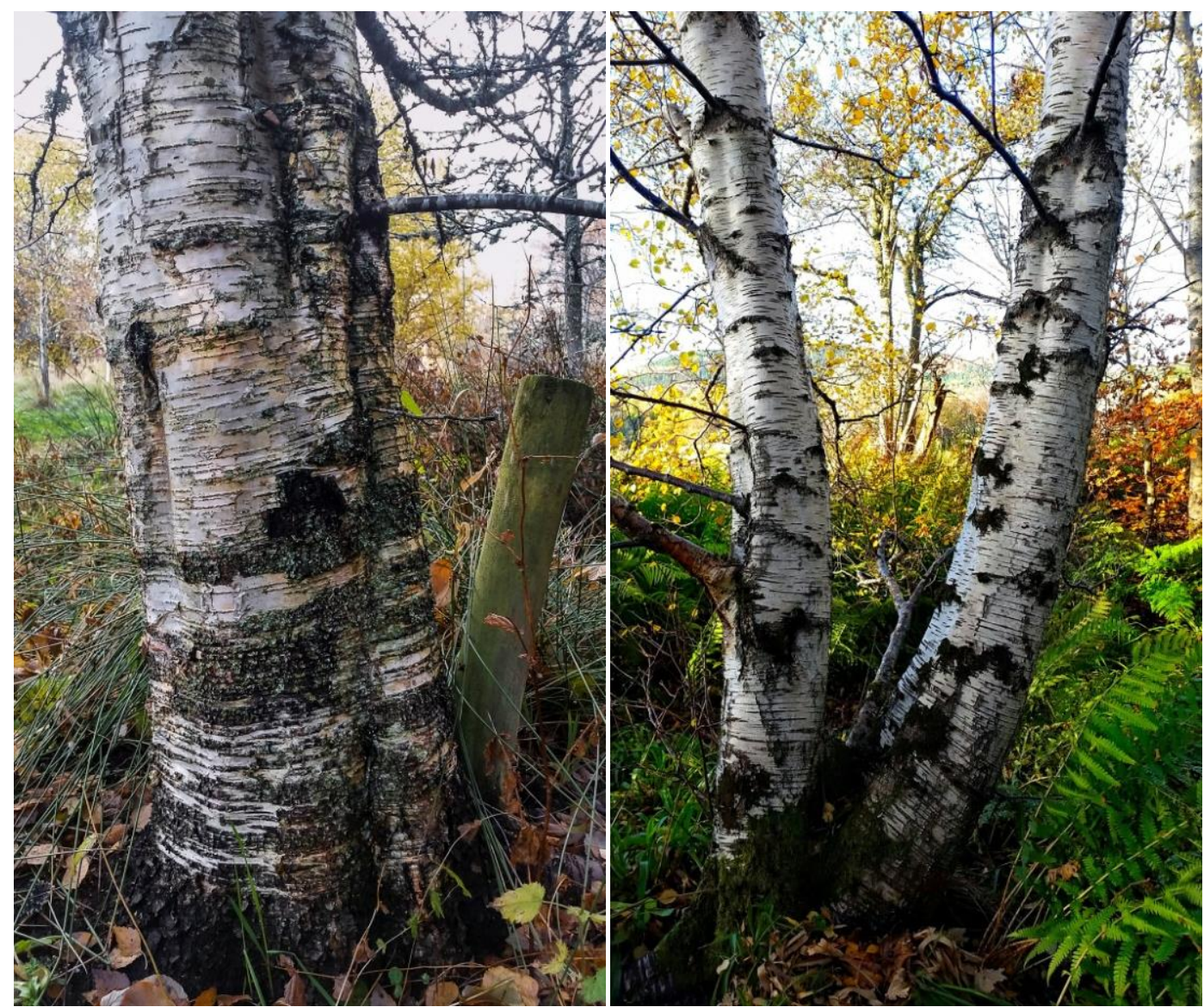

Figure 11. Betula pubescens subsp. pubescens lower trunks, showing prominent horizontal lenticels 


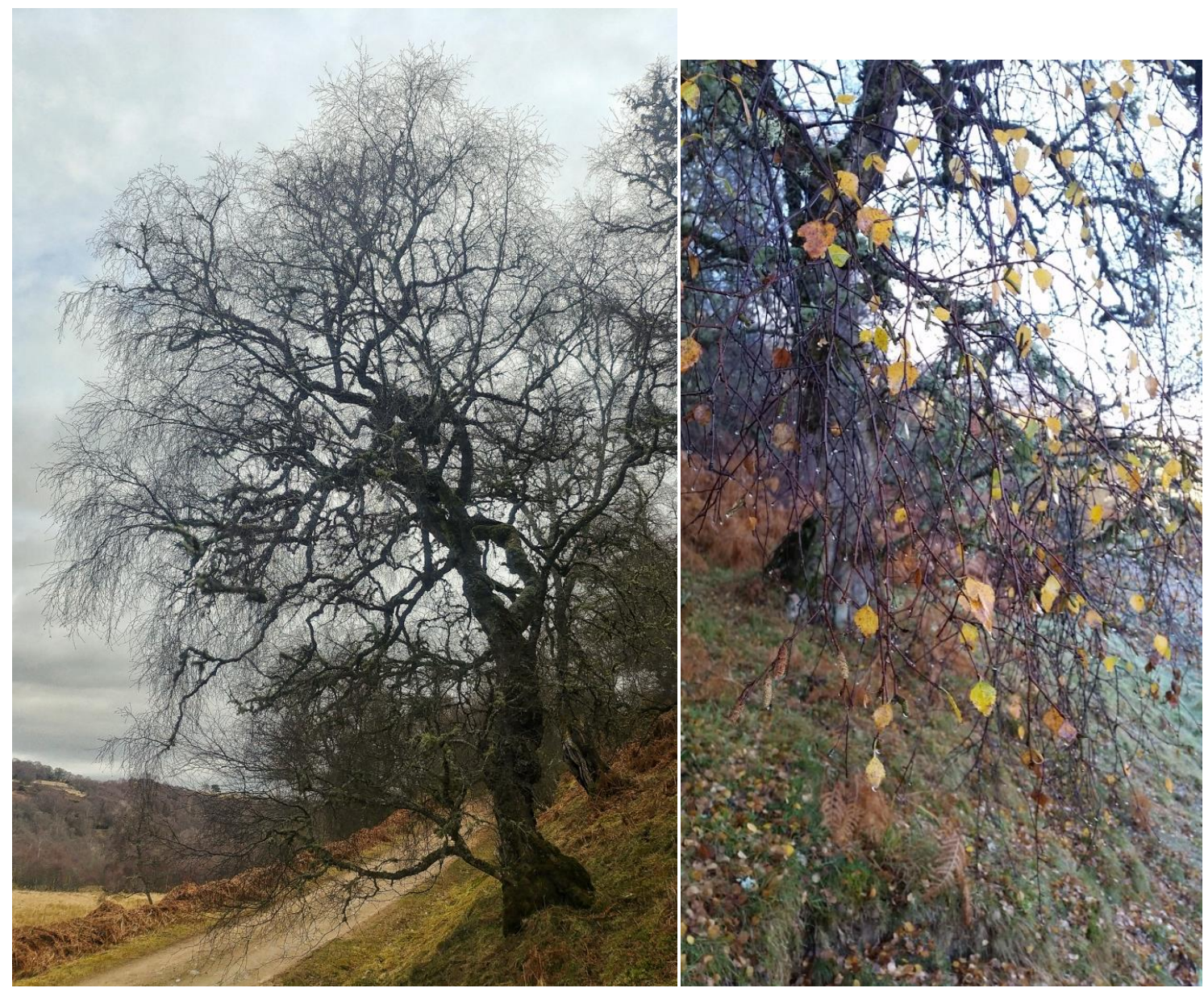

Figure 12. Betula pubescens var. fragrans

A large tree showing complex branching and pendulous twigs on lower branches

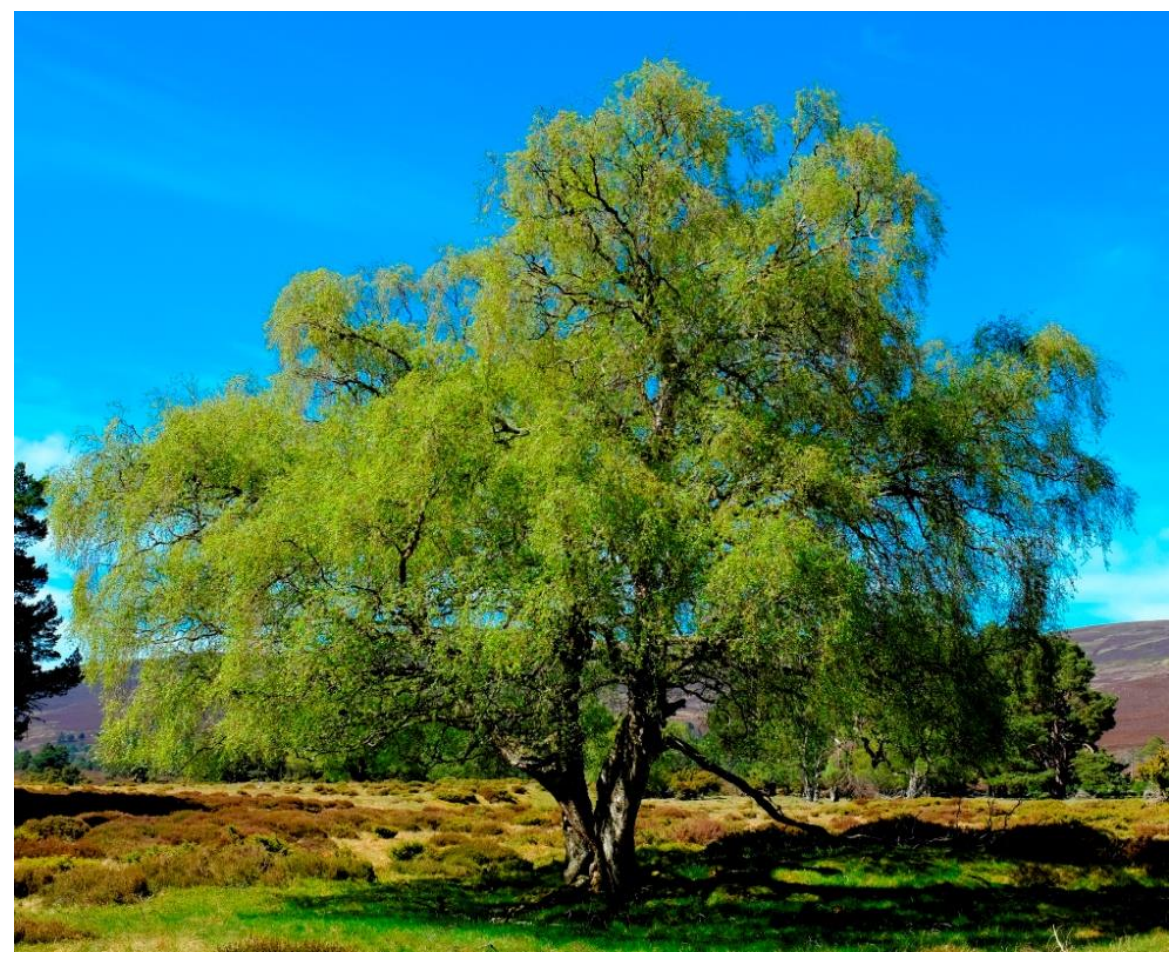

Figure 13. Betula pubescens var. fragrans 

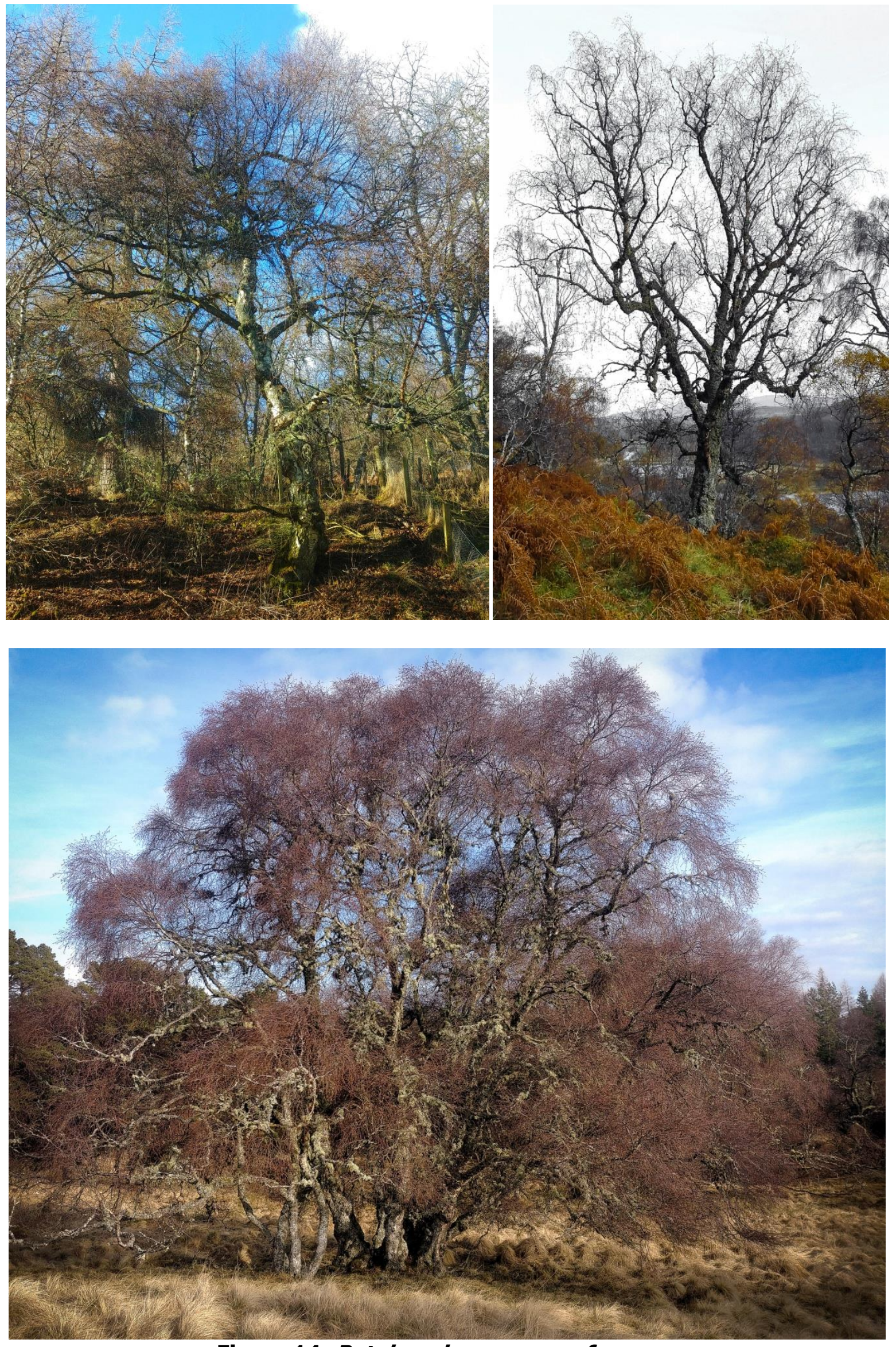

Figure 14. Betula pubescens var. fragrans 


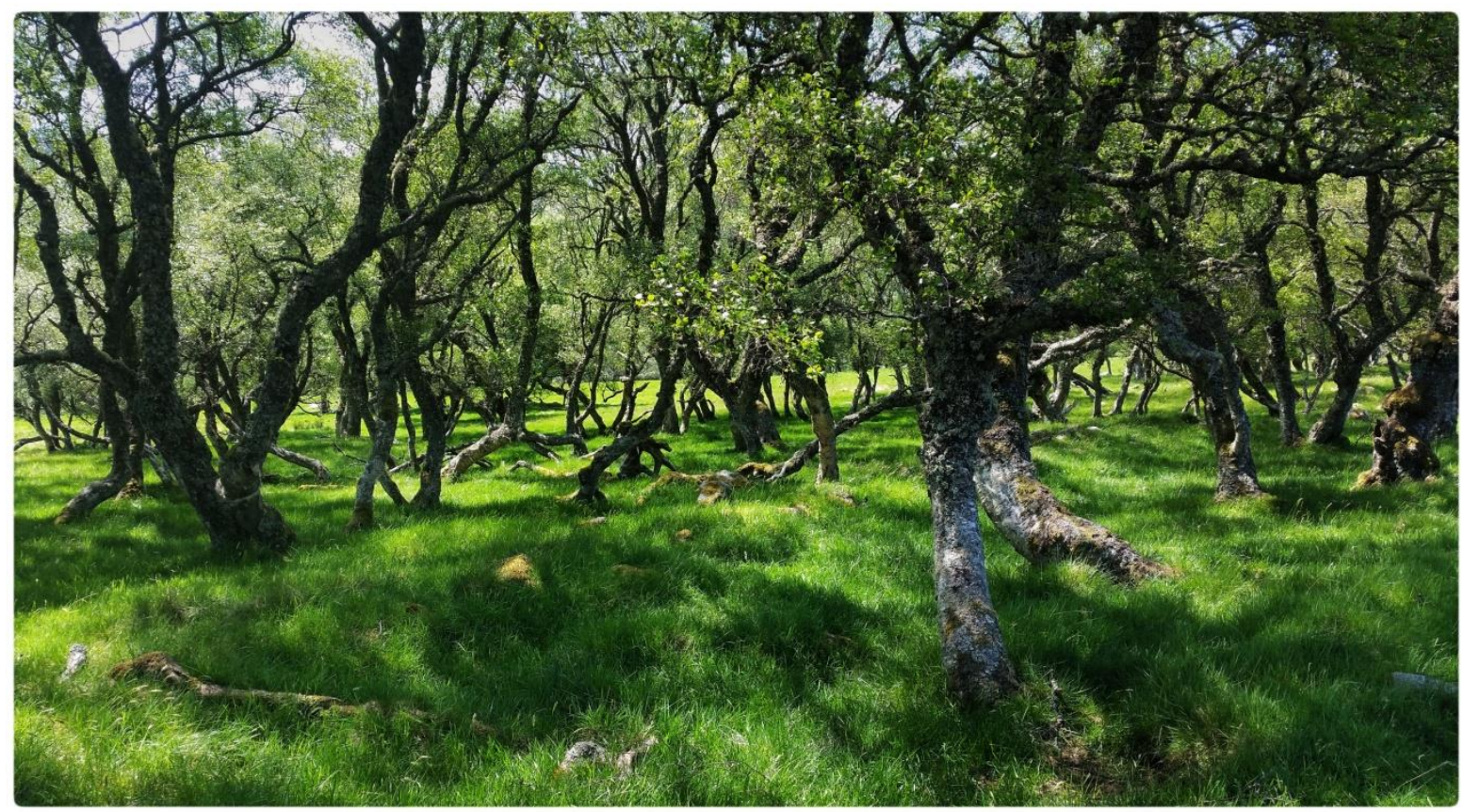

Figure 15. Grazed Betula pubescens var. fragrans woodland

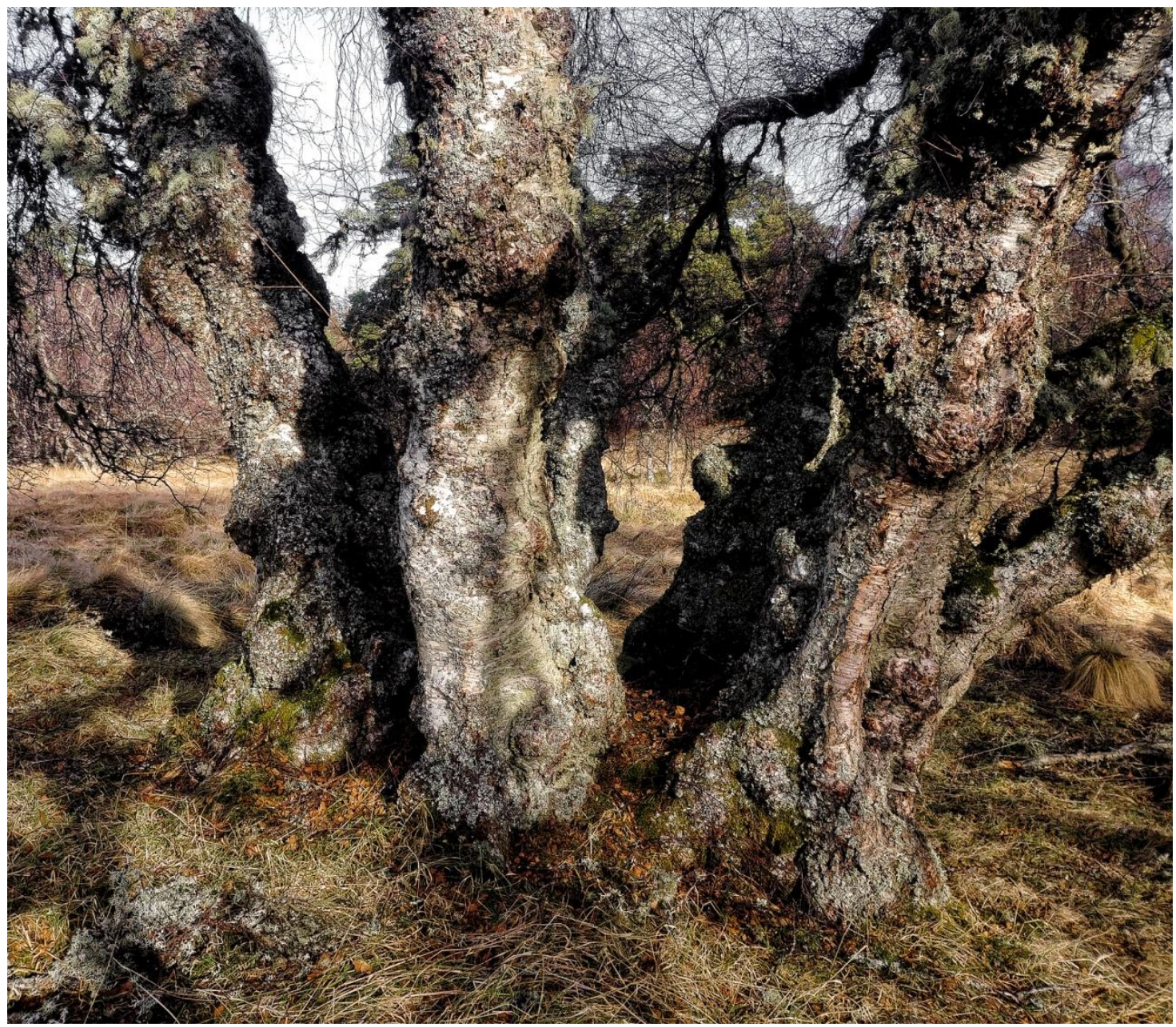

Figure 16. Betula pubescens var. fragrans - multi-trunked old tree 


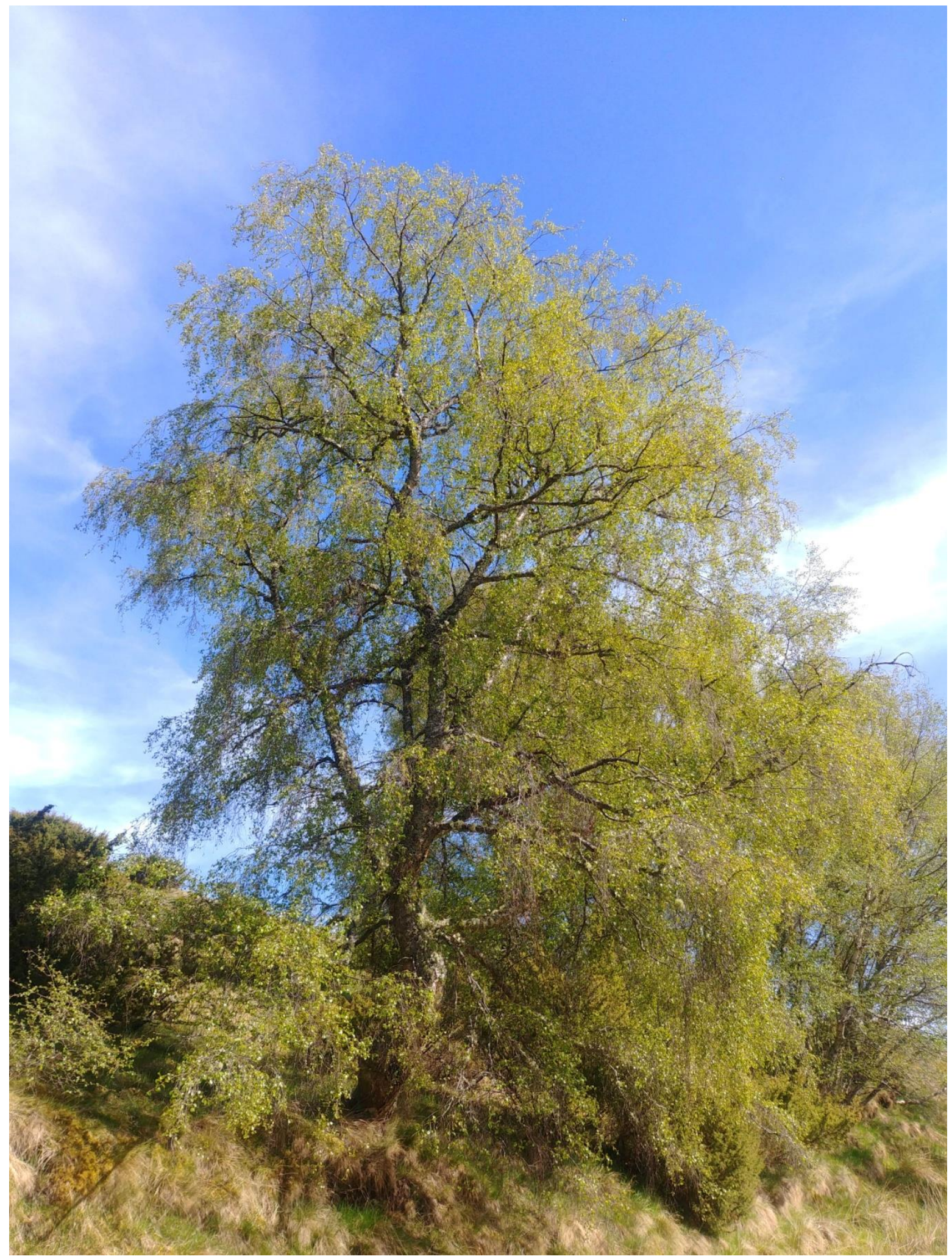

Figure 17. Betula pubescens var. fragrans

(unusually pendulous form that, from a distance, might be mistaken for $B$. pendula) 


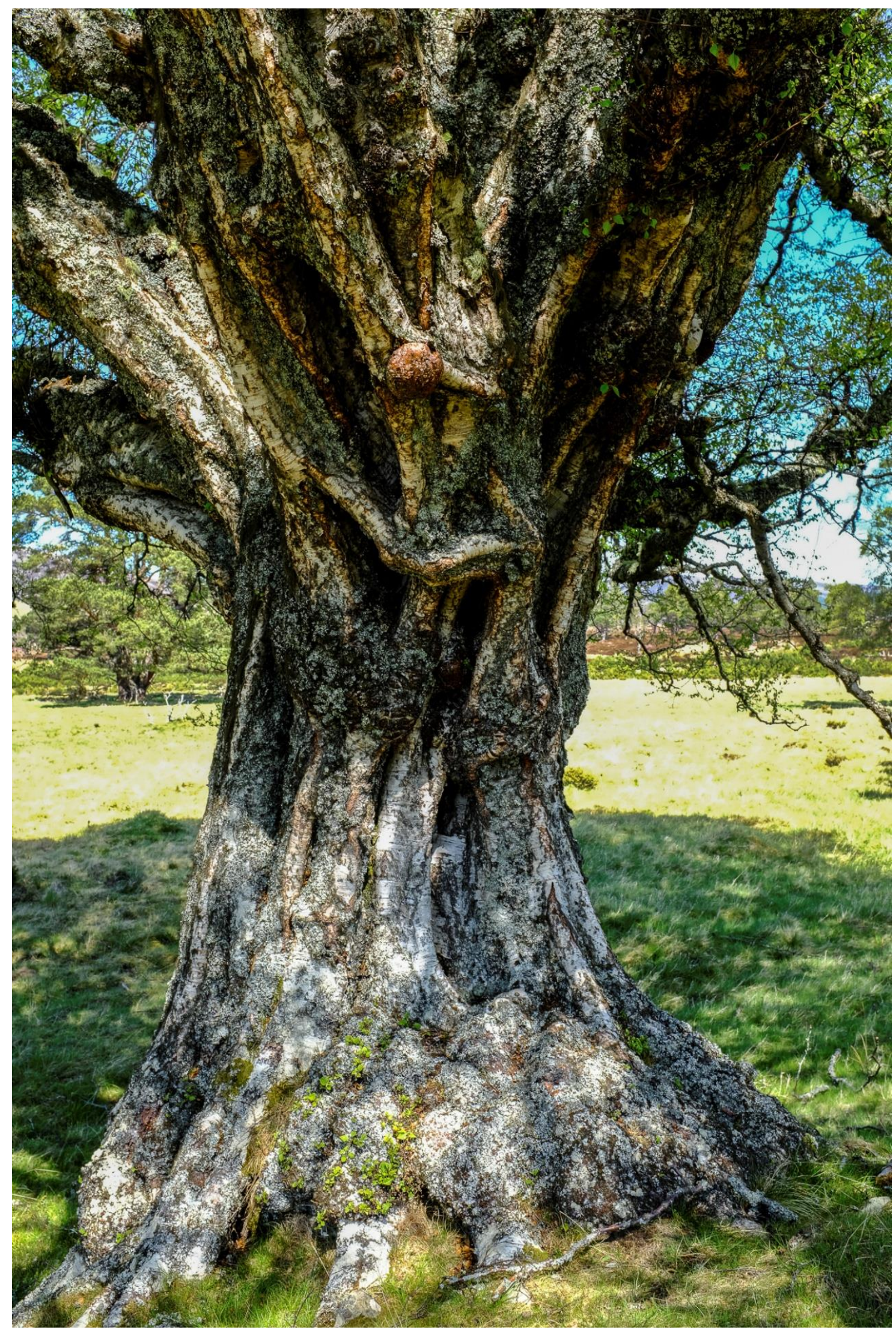

Figure 18. Betula pubescens var. fragrans Old tree, with fluting of trunk (an extreme example) 


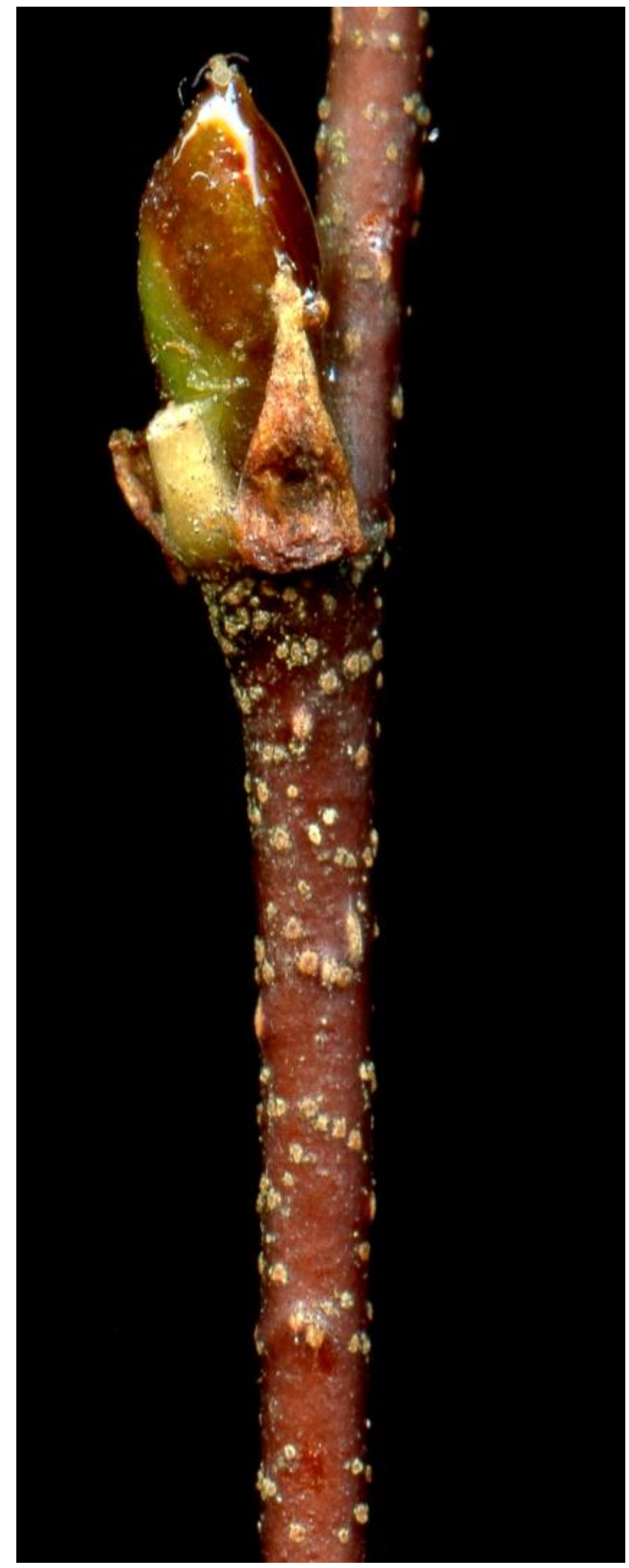

Figure 19. Betula pubescens var. fragrans

(glabrous young twig with glutinous bud, lenticels and glands 

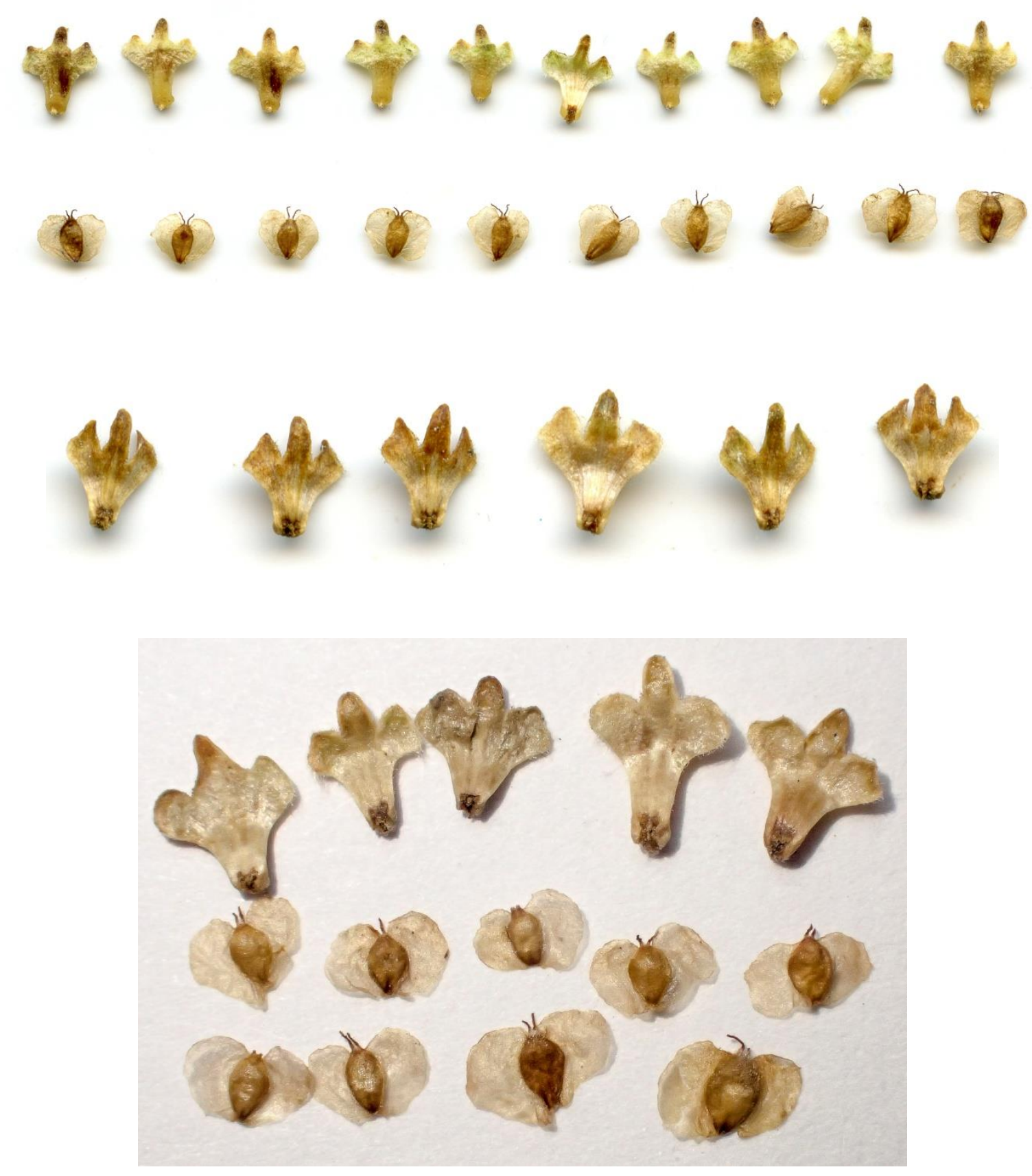

Figure 20. Betula pubescens female catkin scales and fruits (lower image @ John Crossley) 

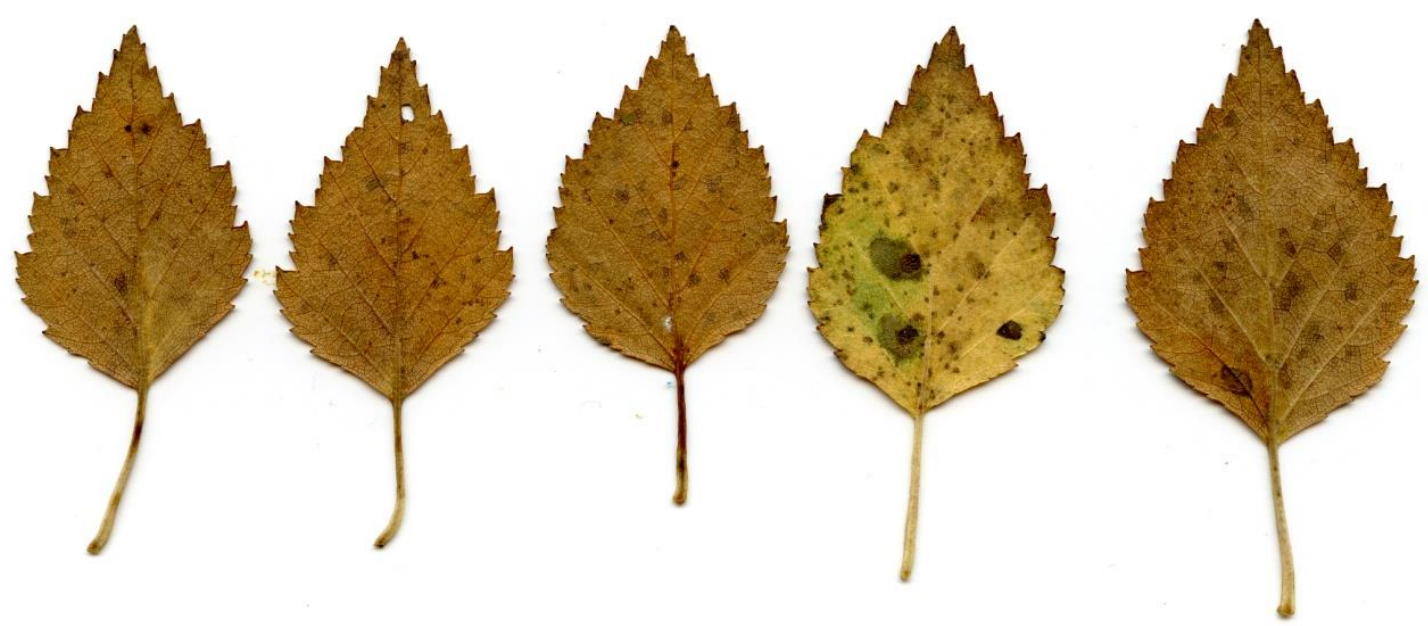

$\begin{array}{lllllllllllllll}10 & 20 & 30 & 40 & 50 & 60 & 70 & 80 & 90 & 100 & 10 & 120 & 130 & 140 & 150\end{array}$

Figure 21. Betula pubescens subsp. pubescens

Leaves from tree in Fig. 10 (right). Leaf shape (teeth \pm double, apex acute) suggests introgression from $B$. pendula, but all other ID features indicate that the tree is B. pubescens: (Fig. 11 (left) (lower trunk) and Fig. 20 (female catkin scales, third row from top).
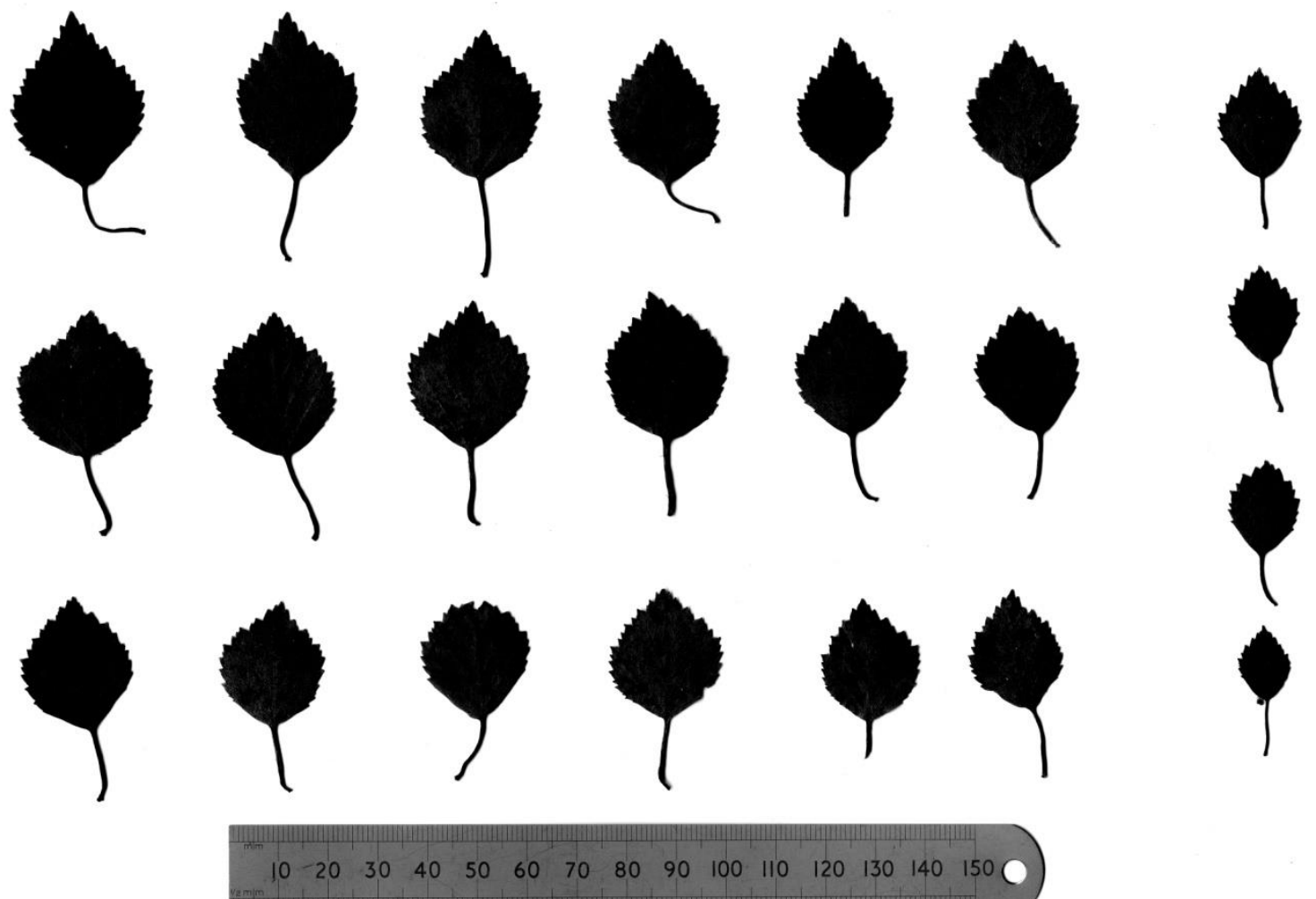

Figure 22. Betula pubescens var. fragrans leaves from single tree (Fig. 14, top left). Small leaves in right hand column are from apex of long shoots. Other leaves are typical short shoot leaves 


\section{2). The occurrence of the $F 1$ hybrid between $B$. pendula and $B$. pubescens, Betula x aurata (Borkh.).}

Trees intermediate in morphology between the parents have been considered to be hybrids and reported as common and widespread (Marshall, 1914; Walters, 1975). It is suggested by Walters (1975) that their common occurrence here is correlated with the secondary status of much birch woodland in which the original ecological isolation of the two species has broken down. Further discussion of naturally occurring and artificially created hybrids is contained in Atkinson (1992) and in the Hybrid Flora (Stace et al., 2015), which reviews the pre-2000 literature.

However, while the $F 1$ triploid hybrid $(2 n=42)$ does occur, it appears to be rare. For example, studies in secondary mixed species birch woodland in East Anglia (Gill \& Davy, 1983; Howland et al., 1995) detected no F1 hybrids or aneuploids, within samples of 50 and 20 Birch trees. Zohren et al. (2016) used restriction site-associated (RAD) markers to analyse introgression within $37 B$. pendula and 131 B. pubescens samples, from sites across the whole of Great Britain. They only detected a single F1 hybrid.

Chromosome counts do not resolve the issue, as trees with $2 \mathrm{n}=42$, may be $B$. $x$ aurata, or $B$. pendula (via unreduced gametes of one parent) or even $B$. pubescens (via double reduction meiosis of one parent), though the latter is doubtful (H. McAllister pers. comm.). To complicate matters further, tetraploid hybrids $(2 \mathrm{n}=56)$ can be formed by unreduced gametes from $B$. pendula (Nokes, 1979).

F1 tetraploid hybrids would be expected to be exactly intermediate in morphology, while F1 triploid hybrids would be more like B. pubescens. Given widespread introgression from $B$. pendula into $B$. pubescens (Section 3 ), it is most unlikely that triploid hybrids can be identified with confidence in the field.

As stated earlier, trees of intermediate appearance are not unusual and can lead to difficulties in identification. In studies in secondary birch woodland in East Anglia (Gill \& Davy, 1983; Howland et al., 1995), diploids showed less morphological and molecular variation than tetraploids. Morphologically the diploids were a good match for $B$. pendula, while the tetraploids were much more variable. The range of variation in the tetraploids included some trees which corresponded well with $B$. pubescens and others which corresponded well with $B$. pendula; most of the tetraploids were intermediate in their expression of at least one, and usually more than one, of the characters measured (Gill \& Davy, 1983).

Forbes \& Kenworthy (1973), mapped the distribution of $B$. pendula and $B$. pubescens in the whole of the upper River Dee catchment in Aberdeenshire. They commented "We have obviated the problem of separating all individuals into $B$. pendula and $B$. pubescens by taking as a unit not individual trees but stands of trees. Although every tree in a stand cannot be assigned to one species or the other, it is possible, on the basis of trees which have been positively identified, to estimate the proportion of the two species which are present in the stand. This involves the assumption that the proportion of $B$. pendula in the unidentified trees is the same as that in the trees which can be identified. Errors arising from this assumption are insignificant, since in practice it is seldom that more than 10 percent of the trees in a stand cannot be placed in one species or the other." This approach provides a practical solution.

However, such an approach may inflate the actual abundance of $B$. pendula. $\mathrm{H}$. McAllister's suggestion (pers. comm.) is to certainly identify $B$. pendula (if present), all the remaining trees are likely to be tetraploid and freely inter-fertile, 
hence forming a breeding unit distinct from a 'pure' $B$. pendula breeding population. The tetraploids, though variable in appearance, can all be referred to $B$. pubescens. The above is as would be expected as diploids $(2 n=28)$ can produce unreduced gametes $(n=28)$ which can fertilise the tetraploid $(2 n=56)$ B. pubescens, producing tetraploid hybrids inter-fertile with 'true' pure $B$. pubescens. There is no obvious way that tetraploid $B$. pubescens is likely to produce a gamete with $n=14$ to transfer genes from $B$. pubescens to the diploid $B$. pendula. Double reduction at meiosis is possible but likely to be extremely rare or nonexistent.

From my own observations in Strathspey, in north Scotland, it is straightforward to identify typical examples of both species, even where they occur in mixed stands, as long as determinations are based on as many identification features as possible (Table 1 ).

\section{3). Introgression from the diploid $(2 n=28) B$. pendula and $B$. nana, into the tetraploid $(2 n=56) B$. pubescens.}

While F1 hybrids may be rare, it has now been elegantly demonstrated (using two different molecular techniques) that introgression is widespread (Wang et al., 2014a and Zohren et al., 2016). Both studies clearly separated $B$. pendula from $B$. pubescens, and both from $B$. nana. Using genotyping at 12 microsatellite loci, and restriction site-associated (RAD) markers, they detected introgression from the two diploid species, $B$. pendula and $B$. nana, into the tetraploid $B$. pubescens, with negligible indication of introgression from $B$. pubescens into the other two species (Zohren et al., 2016). They also found there was an introgression gradient from the north of Scotland and Orkney to the south of England. Introgression from $B$. pendula into $B$. pubescens was very low in the north, increasing to the south. Introgression from $B$. nana into $B$. pubescens was the opposite; very low in the south, higher to the north. Both clines were highly statistically significant. The evidence of introgression from $B$. nana is remarkable, as evidence of its admixture in $B$. pubescens genotypes was detected far to the south of the species' current range in Great Britain. The authors concluded that "a zone of hybridization between $B$. nana and $B$. pubescens moved northwards through the UK since the last glacial maximum, leaving behind a footprint of introgressed genes in the genome of $B$. pubescens".

From the supporting evidence file, Table S1, (Zohren et al., 2016), I have calculated the percentage admixture within samples of $B$. pubescens (Table 2).

Table 2. Introgression of Betula nana and B. pendula into B. pubescens (Zohren et al., 2016).

\begin{tabular}{|l|c|c|c|c|c|}
\hline & & \multicolumn{2}{|c|}{$\begin{array}{c}\text { Percentage } \\
\text { introgression from: }\end{array}$} & \multicolumn{2}{c|}{$\begin{array}{c}\text { Percentage frequency of } \\
\text { samples introgressed from: }\end{array}$} \\
\hline Latitude & (n) & B. nana & $\begin{array}{c}\text { B. } \\
\text { pendula }\end{array}$ & B. nana & B. pendula \\
\hline $\begin{array}{l}\text { North of } 56^{\circ} \mathrm{N} \text {, (ie. } \\
\text { north of Edinburgh) }\end{array}$ & 81 & 2.0 & 1.1 & 93.8 & 85.2 \\
\hline $\begin{array}{l}\text { South of 53N, (ie } \\
\text { south of Stoke on } \\
\begin{array}{l}\text { Trent \& } \\
\text { Nottingham) }\end{array}\end{array}$ & 31 & 0.1 & 7.9 & 22.6 & 93.6 \\
\hline
\end{tabular}


That introgression from $B$. pendula into $B$. pubescens is widespread across Great Britain, and that the degree of introgression is seven times higher in the south than in the north, is an important consideration when identifying $B$. pubescens. While none of these samples would be referred to $B . x$ aurata (if that name is restricted to the $\mathrm{F} 1$ hybrid), it can be hypothesised that $B$. pubescens in the south of Britain will be more likely to show morphological features associated with $B$. pendula, than trees in the north of Britain. That suggestion is supported by studies in secondary birch woodland in East Anglia (Gill \& Davy, 1983; Howland et al., 1995).

Introgression from $B$. nana into $B$. pubescens is only occasional in the south of Britain, and the degree of introgression is merely vestigial; it is truly a 'ghost' of $B$. nana's former range earlier in the current post glacial period. In the north of Britain, introgression from $B$. nana is widespread, and while the degree of introgression is low, it is still higher than that from B. pendula. See Section 7.

\section{4). The occurrence of distinctive local forms, especially of $B$. pubescens.} In their Betula monograph, Ashburner \& McAllister (2013) give great emphasis to chromosome number (ploidy level) when making taxonomic decisions. Given that closely related species with the same ploidy level usually interbreed freely, within a single geographic area there is likely to be only one species with each chromosome number, unless flowering times have little or no overlap. Birches are wind pollinated, and mostly self-incompatible. Pollen can be dispersed over long distances, hence within an area there should be few differences between individuals or populations. This is a good taxonomic and evolutionary argument for lumping rather than splitting taxa, at least at species level.

Nevertheless, morphologically more or less distinctive forms of B. pubescens do exist within relatively restricted geographic areas. If we were to consider the whole of Britain as a unit, we might expect all $B$. pubescens to be broadly similar in appearance. Even allowing for the observed gradients in introgression from $B$. pendula and $B$. nana (discussed above), $B$. pubescens is not homogenous.

Warburg (1952) stated that B. pubescens was (in Britain and Ireland) "A very variable species perhaps divisible into several subspecies", probably reflecting Marshall's account of Betula in The Cambridge British Flora (Marshall, 1914) in which he divided $B$. pubescens into five varieties.

Two of Marshall's taxa (B. pubescens var. vestita Grenier et Gordon and $B$. pubescens var. glabrata Wahlenberg) refer to tall, erect growing trees. The former, and perhaps the latter, fall within Warburg's subsp. pubescens, and both fall within Ashburner \& McAllister's var. pubescens. Marshall describes his var. vestita as common in lowland England. From his description and illustrations, this variety appears to exhibit signs of introgression from $B$. pendula. His var. glabrata, he describes as "commoner among the hills of the west and north of Great Britain than in the lowlands of the south and east; on lowland peat-moors in the north of England; common on the Pennines".

Two of Marshall's taxa (B. pubescens var. microphylla E.S. Marshall and $B$. pubescens var. sudetica E.S. Marshall) he described as taken "together are almost sufficiently distinct from the other forms of B. pubescens to justify their being regarded as a separate species". His var. microphylla is clearly the same taxon as Ashburner \& McAllister's var. fragrans, though there are discrepancies in some of the details, i.e. Marshall states the bark is brown and shining (cf. white or greywhite, sometimes brown) and the female catkins are suberect (cf. pendulous). He 
described it as rare in England and Wales, locally abundant in Scotland. Marshall's var. sudetica, is perhaps just a variant with narrower rhomboidal leaves, with acute apices, cuneate base and coarser teeth. He thought it rare.

Marshall described his final variety, B. pubescens var. alpigena Blytt, as a low tree or shrub, branches tortuous, leaves deeply, singly or doubly dentate, occurring between 500-700 m AOD in Scotland. It is not clear how to interpret this taxon. It is not illustrated in the Cambridge British Flora. There is material in the herbarium at Cambridge, but images are not available on line. Sell \& Murrell (2018), who were based at Cambridge when writing their Flora do not refer to it, but would have been familiar with Marshall's collections.

At least two other additional forms within $B$. pubescens sensu lato have been described in Britain. Ashburner \& McAllister (2013, pp. 313-314) mention a very distinctive form of $B$. pubescens (which they chose not to name) on the fringes of Dartmoor (in SW England) and in Brittany (NW France), sometimes referred to as the 'brown birch'. This is a tall tree, with whitish-brown or brown bark, velvety-hairy shoots, twigs and leaves, and twigs \pm rough with brown resinous warts. It is part of the variation within their var. pubescens.

Trees closer to $B$. pendula in general appearance, but with persistent abaxial axillary hair tufts on leaves are tetraploids, the result of introgression from $B$. pendula into B. pubescens. Such trees in the Cantabrian Mountains in northern Spain are Betula celtiberica Rothm. \& Vasc.. Ashburner \& McAllister (2013) accept B. celtiberica as occurring in the Cantabrian Mountains, but consider other populations in mountain ranges in Spain and Portugal, formerly identified as $B$. celtiberica, as more likely to be $B$. pendula or $B$. pubescens. They consider $B$. celtiberica to be a stabilised tetraploid population derived from $B$. pubescens heavily introgressed with $B$. pendula, maintaining itself in geographic (and hence reproductive) isolation from populations of $B$. pubescens. Hence it is acting as a species. Correctly identified trees from the Cantabrian mountains are at Ness Botanic Gardens, 10 miles north-west of Chester; and Stone Lane Gardens, Devon, 15 miles west of Exeter (both open to the public).

Betula celtiberica has been reported, mainly from Wales, as well as Arran (Chater, 2010a, Chater, 2010b, Sell \& Murrell, 2018) and is included as $B$. pubescens subsp. celtiberica (Rothm. \& Vasc.) Rivas Mart. in the $4^{\text {th }}$ edition of Stace's Flora (Stace, 2019). Sell \& Murrell (2018) report it as planted in Cambridgeshire and probably planted widely elsewhere. Chater (2010b) records it as a native and occasionally planted tree in Cardiganshire (v.c.46). However, the RHS website lists no suppliers for this species, so nurseries may be listing this tree under a different name.

Tetraploid populations of Betula in an area will be expected to form an interfertile breeding unit, and so, for trees with 'celtiberica' morphology to persist, there would have to be some mechanism that created reproductive isolation, eg. period of flowering, which could be correlated with altitude. Alternatively, trees with 'celtiberica' morphology might repeatedly arise de novo through hybridisation and introgression.

These trees, very distinctive in Cardiganshire (A. Chater pers. comm.) require further study. The application of molecular techniques will be required to establish their links to other Betula populations. Currently the more parsimonious explanation is that trees with the appearance of 'celtiberica' are part of the variation within British $B$. pubescens, due to introgression from $B$. pendula, a view with which $\mathrm{H}$. McAllister agrees (pers. comm. March 2020). 
A selection of images of material from Puerto de Pajares, Oviedo, Spain can be viewed at the Arboretum Wespelaar website. Fig. 23 shows typical leaves from this location. Fig. 24 shows a Cardiganshire (west Wales) example of what is identified as B. celtiberica by A. Chater and P. Sell.

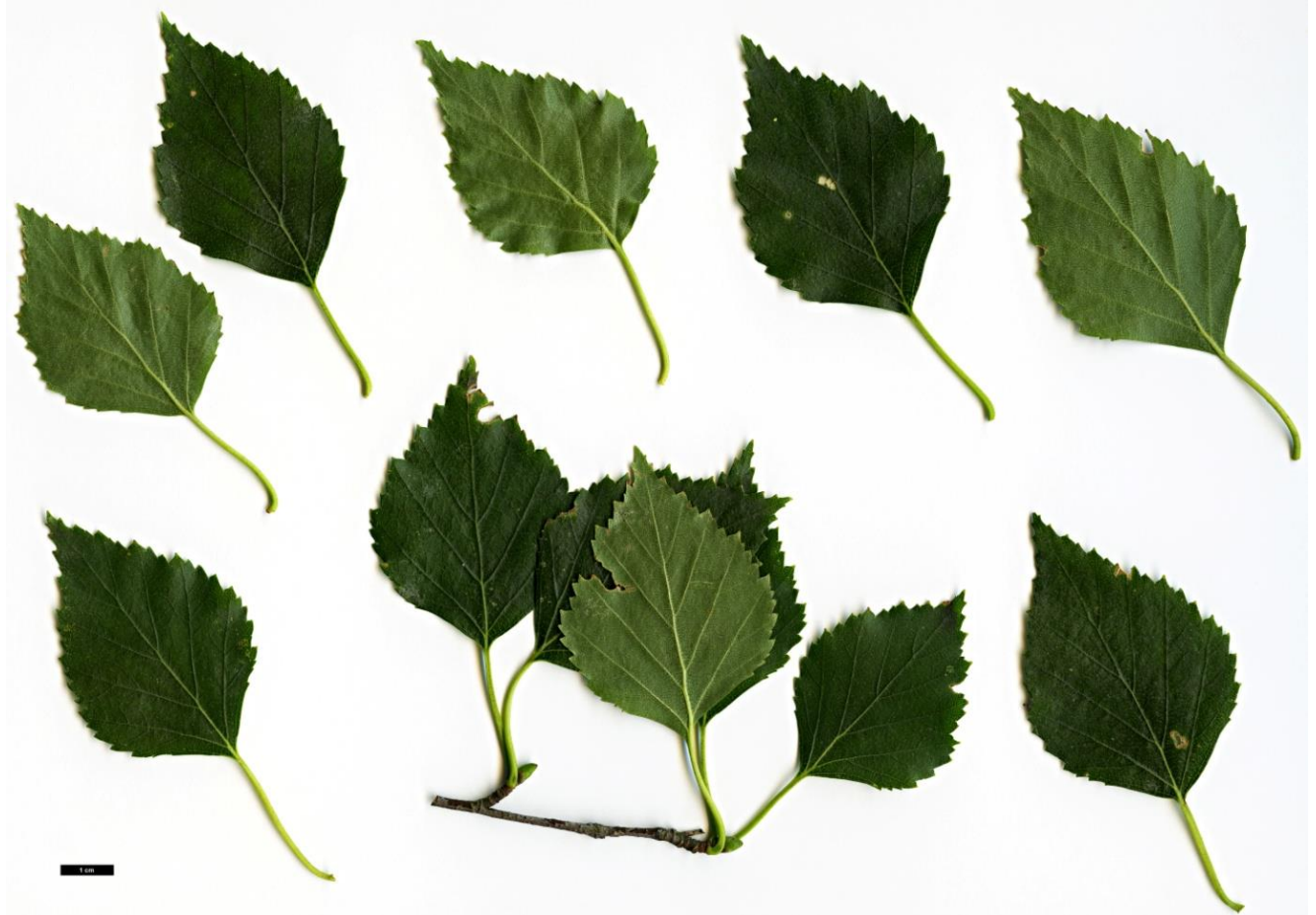

Figure 23. Betula celtiberica - Puerto de Pajares, Oviedo, Spain. @ Jan De Langhe - Arboretum Wespelaar / Ghent University Botanical Garden

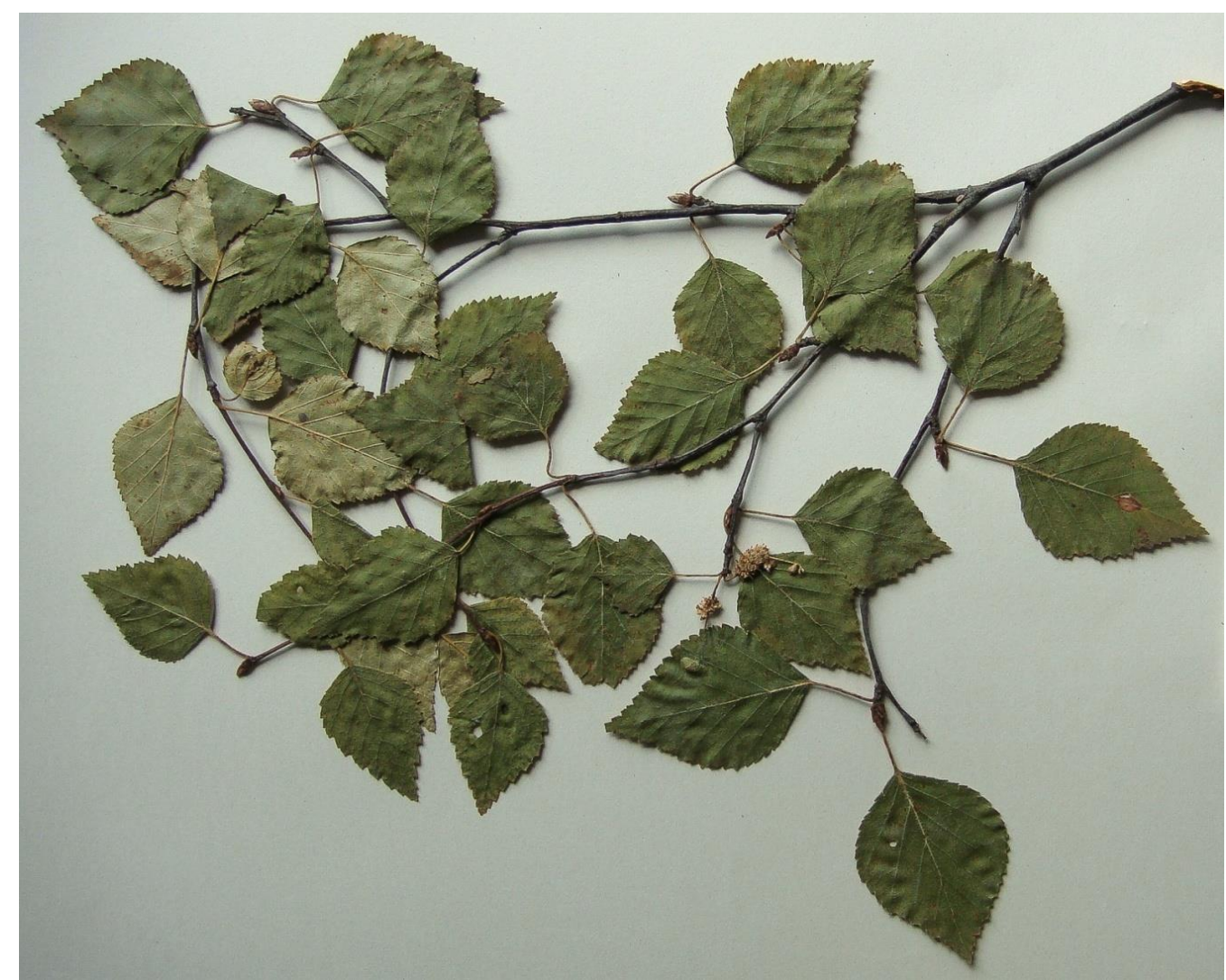

Figure 24. Betula celtiberica. Pontrhyd-y-groes area v.c.46 @ A.0. Chater 


\section{5). Planting of alien (to the local area) genotypes and species, and effects of habitat disturbance.}

In relatively undisturbed habitats, $B$. pendula and $B$. pubescens occupy rather different habitats, their distributions differ somewhat, and $B$. pubescens occurs at higher altitude. With disturbance to habitats, road and track construction, tree felling and planting, these differences have partially broken down. For example, Abernethy Forest in the Highlands is the largest of the remnant native pinewoods in Scotland. Within the core native pinewood only B. pubescens occurs. However, $B$. pendula is now colonising the verges of manmade tracks through the forest. On an area of bog, previously drained and planted with Pinus contorta (Lodgepole Pine), the non-native pines have been removed and the site re-wetted. The area now has dense regeneration of $B$. pendula, where none would have been expected before.

Provenance of planting stock is often not local. In Strathspey, in the

Cairngorms, occasional B. pubescens is found as a planted tree. Such examples are clearly subsp. pubescens, whereas the usual type found in semi-natural woods locally is var. fragrans.

It is especially concerning that $B$. pendula is sometimes being planted beyond its native distribution in the far north and west of Scotland, potentially compromising the small-leaved $B$. pubescens in this area which has, to date, extremely low introgression from $B$. pendula. Betula nana and $B$. pendula have, at tetrad scale, allopatric distributions, with virtually no overlap. Hence, despite both being diploids, hybridization and introgression is rare. Wang et al (2014a), found diploid hybrids amongst seedlings grown from seeds collected from $B$. nana in Scotland, in an area recently planted with $B$. pendula, suggesting that $B$. nana $\times B$. pendula hybrids do form in Scotland. Maintenance of the geographical separation between $B$. nana and $B$. pendula may be key to preventing future hybridization between them.

Many Betula species are grown in gardens and as street trees, and some are appearing in new woodland plantings. The most commonly seen are probably very white barked forms of $B$. utilis subsp. jacquemontii (with 'knobbly' male catkins) and its probable hybrid with B. ermanii, $B$. 'Doorenbos' (male catkins not 'knobbly' but with some fruiting catkins more or less upright/erect suggesting $B$. ermanii in its parentage). Of the other most widespread non native Betula, B. papyrifera (Paper Birch) should be particularly kept in mind. Some forms of this species closely mimic $B$. pubescens (Figs. 25 and 26). It has large ovate leaves, hairy in the leaf axils below. The fruiting scales are variable in shape; the lateral lobes may point forward as in B. pubescens or (as in Fig. 26) have lateral lobes with a shape similar to $B$. pendula. Seedlings have very hairy stems. 

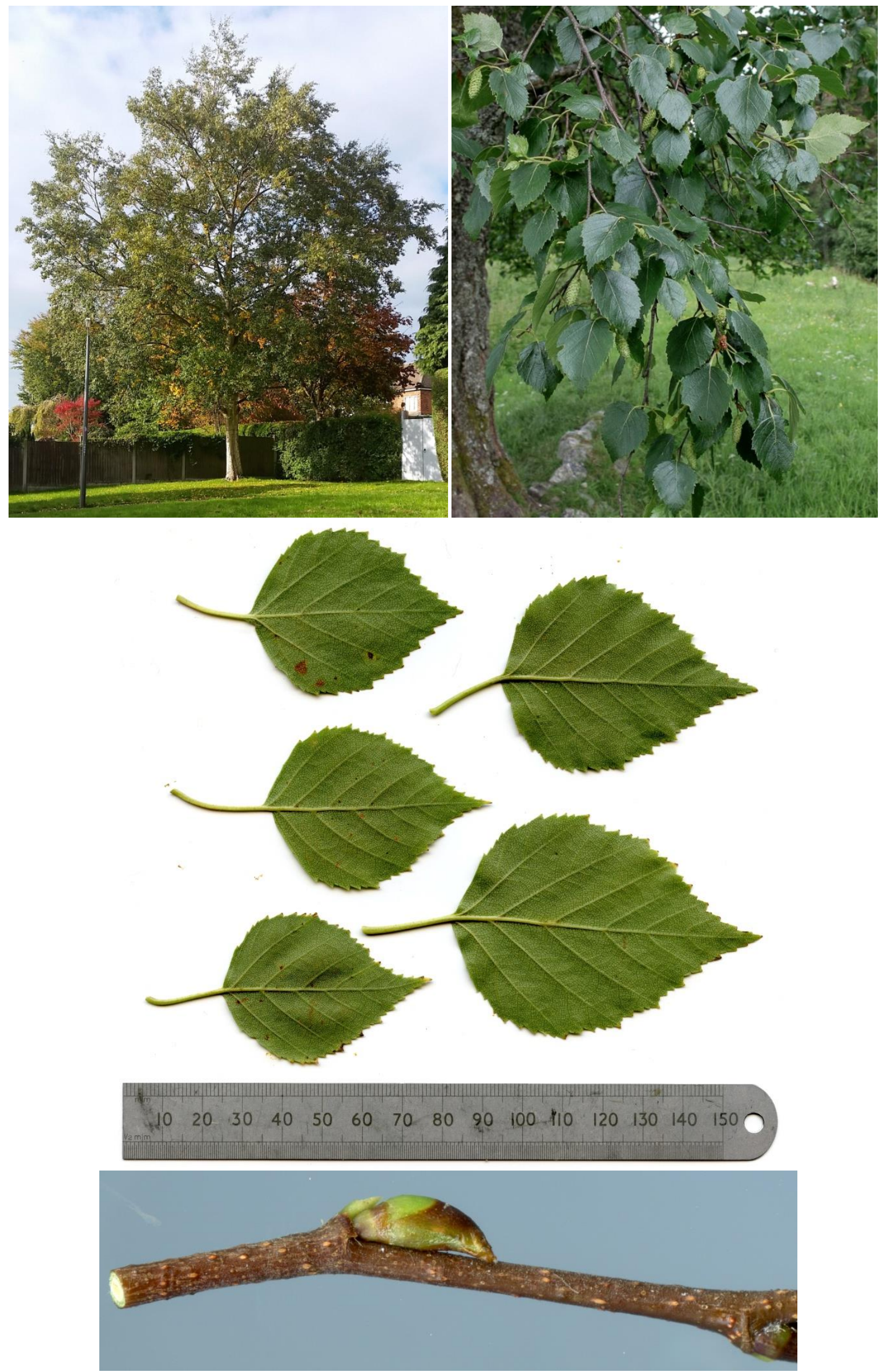
Figure 25. Betula papyrifera. Top left, centre \& bottom - planted street tree, Ashbourne, v.c.57; top right - probably planted tree in wild location, Strath Mashie, v.c.96
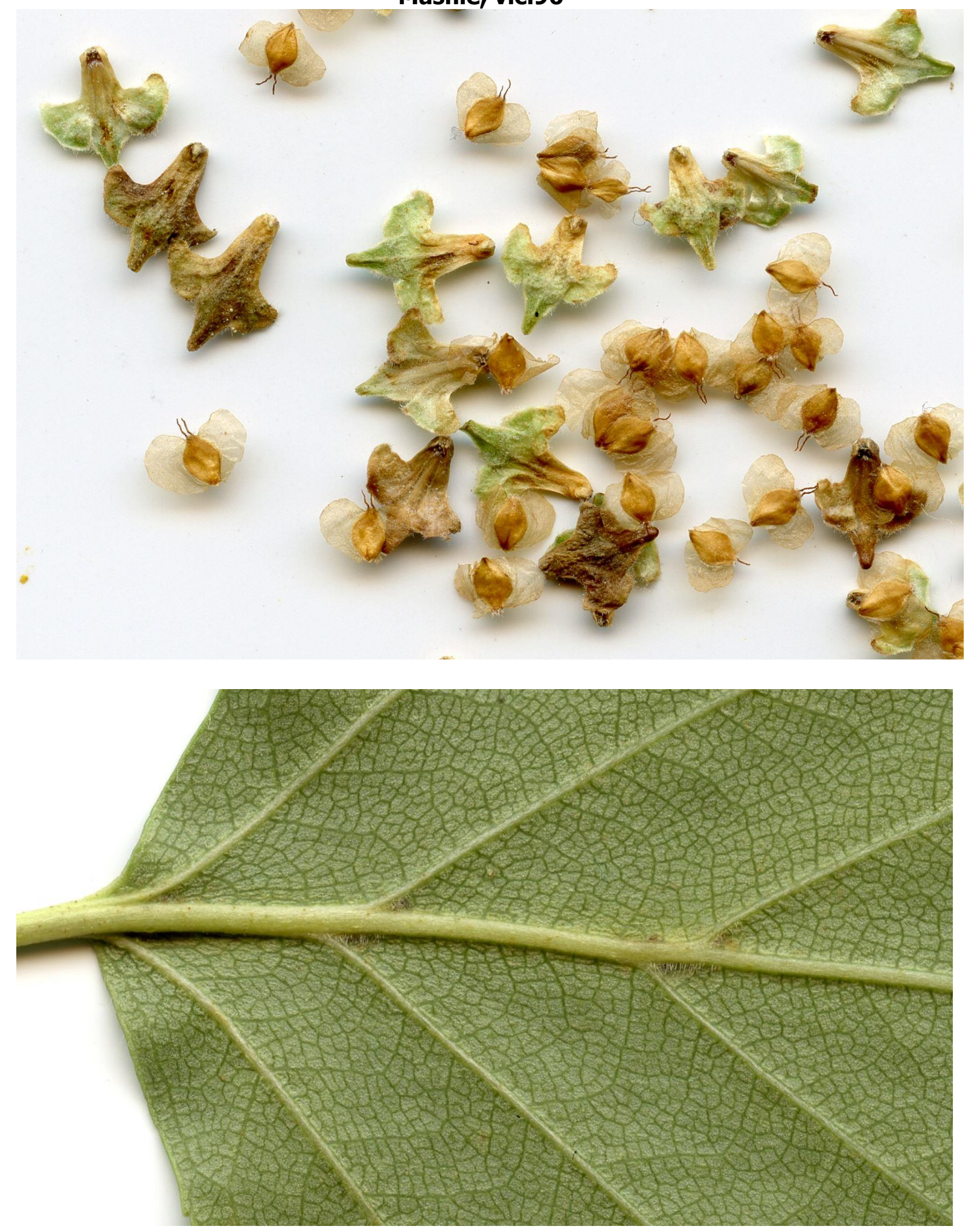

Figure 26. Betula papyrifera. Top - female catkin scales and fruits; bottom - leaf underside detail (hair tufts in vein axils - veins have sparse silky hairs not visible on scan). Planted street tree, Ashbourne, v.c.57

6). Misapplication of names to taxa within B. pubescens. 
The name $B$. pubescens subsp. pubescens has been used in all British Floras since Warburg's account (Clapham et al., 1952). Ashburner \& McAllister (2013) apply the name at variety level. Other than that the name presents no problems.

However, the small-leaved form of $B$. pubescens in Great Britain has gone by five different names over the last 70 years: Betula pubescens subsp. odorata (Bechst.) E.F.Warb., B. pubescens subsp. carpatica (Willd.) Ascherson \& Graebner, $B$. pubescens subsp. tortuosa (Ledeb.) Nyman and B. odorata Bechst. All these names were incorrectly applied to this taxon.

Gardiner (1984) noted that the small-leaved B. pubescens in the north west Highlands of Scotland, were distinctive cf. other populations in lowland Britain and Europe. Ashburner \& McAllister (2013) agreed that these trees were distinctive. In their monograph it is named $B$. pubescens var. fragrans.

The incorrect or misapplied names are discussed below.

\section{Betula pubescens subsp. odorata (Bechst.) E.F.Warb and B. odorata Bechst.}

Gardiner (1984) provides a summary of Bechstein's original description of $B$. odorata. Bechstein described it as a single-stemmed tree, taller than $B$. pendula and with coarser branching, bark strikingly white, twigs pubescent without warts, leaves larger and broader, buds viscid, aromatic. Apart from the viscid buds and being aromatic, the description is almost the complete opposite of the taxon that Warburg described as B. pubescens subsp. odorata. Gardiner therefore concluded that $B$. odorata falls within B. pubescens subsp. pubescens. Marshall (1914) had synonymised $B$. odorata with his $B$. pubescens var. vestita, which falls within Warburg's subsp. pubescens, so it is surprising that Warburg used this name for the small-leaved taxon. Sell \& Murrell (2018) elevate this taxon to a full species, $B$. odorata Bechst. Putting aside that it is debateable to recognise the taxon at species level, the name is incorrect. Ashburner \& McAllister (2013) synonymised B. odorata with $B$. pubescens var. pubescens.

\section{Betula pubescens subsp. carpatica (Willd.) Ascherson \& Graebner}

In Flora Europaea, B. pubescens subsp. odorata and B. odorata are synonymised with B. pubescens subsp. carpatica (Walters, 1964). This name was subsequently adopted in several British accounts, including Clapham et al. (1968) and Clapham et al. (1987).

Marshall (1914) had already synonymised B. carpatica with his B. pubescens var. glabrata Wahlenberg, which falls within Warburg's subsp. pubescens. Ashburner \& McAllister (2013) comment that B. carpatica / var. glabrata do not differ significantly from their var. pubescens.

Betula carpatica Wild. was described from the Carpathian Mountains, and is one of several names that have been applied to disjunct populations of $B$. pubescens s.l. confined to mountains and hills in central and south-eastern Europe (Ashburner \& McAllister, 2013). The Flora Europaea account also states that subsp. carpatica occurs in Arctic Europe, however this has been subsequently rejected (Jonsell, 2000; Väre, 2001).

\section{Betula pubescens subsp. tortuosa (Ledeb.) Nyman}

Based on a principal component analysis of leaf measurements, Gardiner (1984) synonymised B. pubescens subsp. carpatica with $B$. pubescens subsp. tortuosa. He noted that the name tortuosa, when used as a subspecies name, took precedence 
over carpatica, and hence he argued that "both the Arctic populations of Scandinavia, Finland and Russia and the montane populations of southern Europe of $B$. pubescens s.l. may be referred to B. pubescens subsp. tortuosd". As mentioned earlier, Gardiner also noted that the small-leaved birch in the north west Highlands of Scotland, were distinctive from other populations in Europe, and he recommended that they should be recognised at variety level (following Marshall, 1914) as B. pubescens subsp. tortuosa var. microphylla Hartman, though he did not formally publish this combination.

Stace (1991) accepted Gardiner's conclusion, and adopted the name $B$. pubescens subsp. tortuosa for the small-leaved trees of upland areas of northern Britain. This name has been repeated in subsequent editions of this Flora with subsp. carpatica and subsp. odorata (sensu Warburg) as synonyms.

Betula tortuousa Ledeb. was described by Ledebour from the Altai Mountains, on the Russia / Mongolia / China / Kazakhstan border, and so was likely to have little (or no) evolutionary relationship with northern $B$. pubescens affected by introgression from $B$. nana. The type specimen is at St. Petersburg and was not examined by Ashburner \& McAllister in the preparation of their monograph. However, Orlova (1978) in a paper written in Russian, summarised by Hämet-Ahti (1987), showed that there were distinct morphological differences between $B$. tortuosa from the Altai and the 'mountain birch' of NW Europe. Orlova (1978) considered $B$. tortuosa to possibly be a hybrid between $B$. microphylla Bunge and $B$. rotundifolia Spach ( $=B$. glandulosa Michx.). Orlova named the 'mountain birch' of NW Europe $B$. czerepanovii, which Hämet-Ahti (1987) published at subspecies level as $B$. pubescens subsp. czerepanovii (Orlova) Hämet-Ahti.

The Betula account in Flora Nordica (Jonsell, 2000) also rejects the name $B$. tortuosa, agreeing with the conclusions of Orlova and Hämet-Ahti. Jonsell suggests that the 'mountain birch' is the result of introgression from $B$. nana, and that the correct name would be $B$. pubescens subsp. czerepanovii. However, because the transition to $B$. pubescens s.S. is completely clinal, and because the 'mountain birch' is not a homogenous taxon he does not recognise it. Väre (2001) for practical reasons adopts the name $B$. pubescens subsp. czerepanovii. Ashburner \& McAllister (2013) also come to very similar conclusions to Jonsell (2000), but favour taxonomic recognition as B. pubescens var. pumila (L.) Govaerts. (Linnaeus had used the name pumila at variety level in his Flora Suecica, 1745). Unfortunately the name var. pumila invites confusion with the North American Betula pumila (L.).

\section{7). Misleading interpretations of the relationship between the small- leaved $B$. pubescens in the Highlands of Scotland $c f$. Scandinavian 'mountain birch'.}

In Scandinavia and Iceland a more or less distinctive form of $B$. pubescens is dominant in the subalpine zone, often referred to as 'mountain birch (Jonsell, 2000). In recent literature (see Section 6), this is referred to $B$. pubescens subsp. czerepanovii, $B$. pubescens var. pumila, or is not given taxonomic recognition. It was formerly often incorrectly named tortuosa at species or subspecies rank. The adoption of the subspecies name tortuosa in the New Flora (Stace, 1991), wrongly indicates a close similarity of the small-leaved B. pubescens in the Highlands of Scotland, and the Scandinavian 'mountain birch'.

The northern form of $B$. pubescens, i.e. var. pumila, is thought to be derived from subsp./var. pubescens through adaptive selection and introgression from $B$. nana (Ashburner and McAllister, 2013). In Scandinavia and Iceland, both 
introgressed $B$. pubescens and its triploid hybrid with $B$. nana occur, the latter much more frequently than in Scotland (Jonsell, 2000, Thórsson et al., 2007).

In Scotland introgression from B. nana into B. pubescens is frequent, but at a very low level (see Section 3). It is disputed to what extent such introgression is the cause of the small leaf size observed in (at least some) B. pubescens. In the first edition of the New Flora (Stace, 1991) it is suggested that "small-leaved variants of (subsp. tortuosa, sensu Stace) may have arisen by introgression from B. nana". However, the fourth edition (Stace, 2019) says "Suggestions that the small leaves (of subsp. tortuosa) are derived from past hybridisation with $B$. nana are purely conjectural". The earlier suggestion was that only the small-leaved variants of the subspecies were introgressed from B. nana. H. McAllister (pers. comm. 2016) commented that var. fragrans (the widespread small-leaved type in Scotland) shows no signs of morphological influence from $B$. nana. He also added that he would "probably refer some Scottish Betula specimens to var. pumila, though I have not mentioned it in the monograph as occurring in the UK".

Marshall's account of Betula (Marshall, 1914) is instructive. He describes two forms of the $B$. nana $x$ B. pubescens hybrid: $x B$. alpestris Gurke, which he described as very rare (only certainly from Ben Loyal (Fig. 27, left) and Rannoch Moor), and $x B$. intermedia Gurke (Fig. 27, right), which he described as rare, but recorded from several sites in Scotland. (I have retained the hybrid names used by Marshall (1914), to maintain compatibility with his account. However this naming convention is now used for intergeneric hybrids which these are not.)

Marshall also commented that some forms of his var. microphylla (i.e. var fragrans) show a strong resemblance to his $x B$. intermedia. From Marshall's descriptions, his $X B$. alpestris is closer to $B$. nana, probably the $\mathrm{F} 1$ hybrid, and his $X$ $B$. intermedia closer to $B$. pubescens. The latter appear to be backcrosses to $B$. pubescens (or even var. pumila, see below), being taller bushes (to $4 \mathrm{~m}$ ) with morphology of leaves, fruits and fruiting catkin scales closer to $B$. pubescens (Table $3)$.

The Glen Callater plant (Fig. 27, right) was described as a "good sized tree" (Marshall, 1901). Another example collected by Marshall (as x B. intermedia) was from a stream side (1,400 ft.), near Bachnagairn, Clova District, v.c.90, 29/6/1904. "It was about 12 feet $(3.7 \mathrm{~m})$ high, conspicuously differing from the surrounding $B$. pubescens at a good distance by its much darker foliage, thickly interlacing branches, and peculiar rounded outline, which resembled that of a giant bush, rather than of an ordinary tree." (Druce, 1905). 


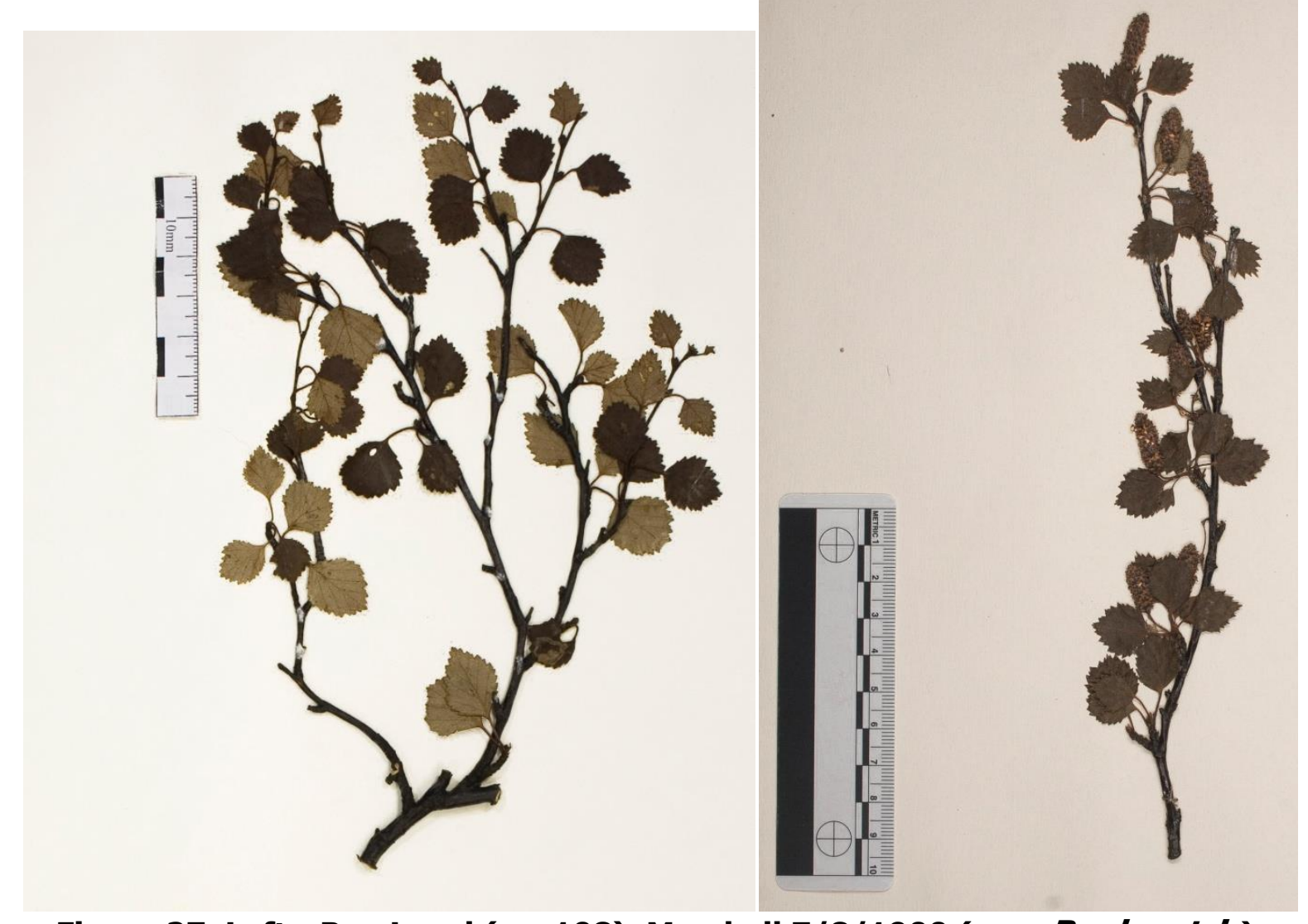

Figure 27. Left - Ben Loyal (v.c.108). Marshall 7/8/1900 (as X B. alpestris). http://herbariaunited.org/specimen/264309/?image

Right - Glen Callater (v.c.92). Marshall 7/1886 (as X B. intermedia). http://herbariaunited.org/specimen/367655/?image

Betula pubescens var. pumila displays evidence of introgression from $B$. nana by its low growing habit, stems growing from the base, with often erect fruiting catkins on densely puberulent twigs. Marshall's $\times$ B. intermedia is probably best treated as B. pubescens var. pumila (H. McAllister, pers. comm., March 2021). See Table 3 for a comparison of these taxa. B. pubescens var. pumila is hitherto unreported from Great Britain. Bushes or trees answering to var. pumila need to be re-found to confirm its presence here.

It is therefore clear that not all examples of small-leaved $B$. pubescens (in Scotland) are var. fragrans. For example, trees on Hoy, Orkney, including those in the northernmost native woodland in Great Britain, at Berriedale, are not var. fragrans (det. H. McAllister, J. Crossley, pers. comm., March, 2021). Leaves from a tree at Quoys (Hoy, Orkney) are illustrated in Fig. 28. This tree, from the shape of the fruits and female catkin scales, is introgressed from $B$. nana. The leaves are very similar to the Glen Callater plant in Fig. 27, but larger, and the fruiting catkins pendulous. $B$. nana does not occur on Orkney, and so this tree must reflect its former presence here, or colonisation of Hoy by heavily introgressed $B$. pubescens at some point in the past. This example, while approaching var. pumila, is probably best recorded as $B$. pubescens, but a form displaying morphological signs of introgression from $B$. nana. 

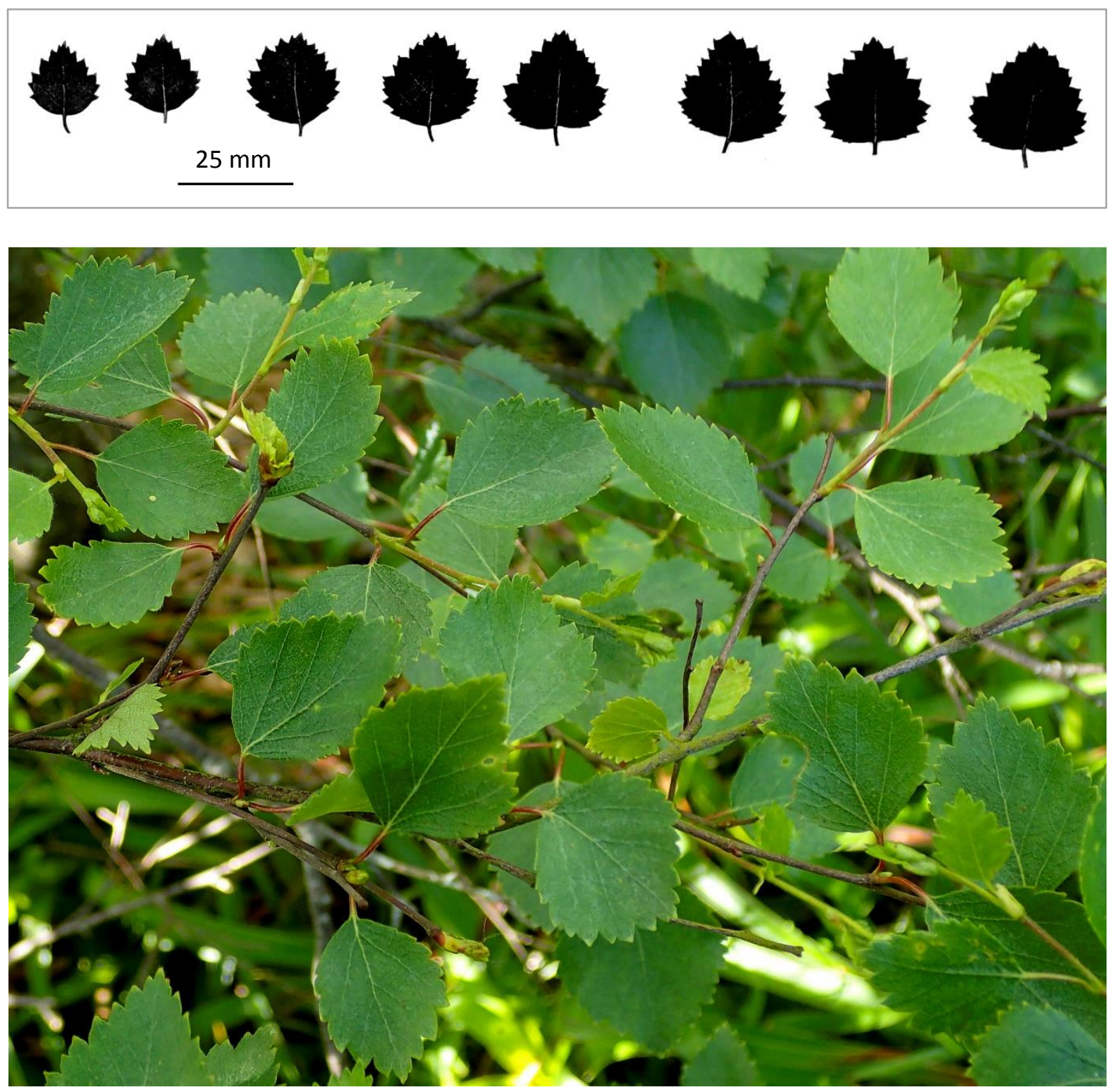

Figure 28. Betula pubescens, small-leaved tree introgressed from $B$. nana Quoys, Hoy, Orkney (v.c.111) @ John Crossley Silhouettes of representative sample of leaves (top) 
Table 3. Identification features of Betula $x$ intermedia (two forms recognised by E.S. Marshall) and B. pubescens var, pumila

\begin{tabular}{|c|c|c|c|}
\hline & $\begin{array}{l}\text { x Betula alpestris } \\
\text { (sensu Marshall, } \\
\text { 1914) }\end{array}$ & $\begin{array}{l}\text { x Betula } \\
\text { intermedia } \\
\text { (sensu Marshall, } \\
\text { 1914) }\end{array}$ & $\begin{array}{l}\text { Betula } \\
\text { pubescens var. } \\
\text { pumila }\end{array}$ \\
\hline Habit / form & $\begin{array}{l}\text { Shrub or undershrub, } \\
\text { max, height } 2 \text { m, } \\
\text { usually much lower }\end{array}$ & $\begin{array}{l}\text { Small tree or large } \\
\text { shrub, height } \\
2.5=4 \text { _m, densely } \\
\text { branched }\end{array}$ & $\begin{array}{l}\text { Small tree (to } \\
6 \text { m) to dwarf } \\
\text { shrub }(0.5 \text { m), } \\
\text { with stiff } \\
\text { branchlets. }\end{array}$ \\
\hline $\begin{array}{l}\text { Young twigs } \\
\text { / branches }\end{array}$ & $\begin{array}{l}\text { Glabrous, rugose, } \\
\text { slightly glandular at } \\
\text { tips. Shorter than in } x \\
\text { B. intermedia. }\end{array}$ & $\begin{array}{l}\text { Usually glabrous } \\
\text { except at tips, where } \\
\text { pubescent \& } \\
\text { glandular. }\end{array}$ & $\begin{array}{l}\text { Thicker than } \\
\text { subsp. } \\
\text { pubescens, to as } \\
\text { thin as } B \text {. nana. } \\
\text { Young shoots } \\
\text { densely hairy. }\end{array}$ \\
\hline Lamina & $\begin{array}{l}\text { Rather smaller than } x \\
B \text {. intermedia, } \\
\text { serrations more } \\
\text { regular, shallower, } \\
\text { blunter. }\end{array}$ & $\begin{array}{l}\text { Suborbicular, or } \\
\text { suborbicular - } \\
\text { rhomboidal, } \\
\text { sometimes broader } \\
\text { than long, truncate or } \\
\text { broadly cuneate at } \\
\text { base, ultimately } \\
\text { glabrous, } \\
\text { subcoriaceous, dark } \\
\text { green above, grey- } \\
\text { green \& strongly } \\
\text { reticulate below. } 1.5 \text { - } \\
1.8 \text { cm long x } 1.0 \text { - } \\
1.5 \text { cm wide. }\end{array}$ & $\begin{array}{l}\text { Usually smaller } \\
\text { than subsp. } \\
\text { pubescens, vein } \\
\text { pairs } 6 \text { or fewer. }\end{array}$ \\
\hline $\begin{array}{l}\text { Fruiting } \\
\text { catkins }\end{array}$ & $\begin{array}{l}\text { Smaller than } \times B \text {. } \\
\text { intermedia. }\end{array}$ & Erect or ascending & Often erect. \\
\hline $\begin{array}{l}\text { Fruiting } \\
\text { scales / } \\
\text { bracts }\end{array}$ & $\begin{array}{l}\text { Scarcely different to } \\
\text { B. nana. }\end{array}$ & $\begin{array}{l}\text { Lateral lobes } \\
\text { ascending. }\end{array}$ & $\begin{array}{l}\text { Lateral lobes } \\
\text { ascending / } \\
\text { erect. }\end{array}$ \\
\hline Nutlet wing & $\begin{array}{l}\text { Narrower than nutlet, } \\
\text { sometimes } \\
\text { rudimentary or } \\
\text { absent. }\end{array}$ & $\begin{array}{l}\text { Variable, sometimes } \\
\text { as } B . \text { pubescens \& } \\
\text { sometimes much } \\
\text { narrower. }\end{array}$ & \\
\hline Frequency & $\begin{array}{l}\text { Very rare. Ben Loyal } \\
\text { (v.c.108) \& Rannoch } \\
\text { Moor (v.c.98). }\end{array}$ & $\begin{array}{l}\text { Rare, more frequent } \\
\text { than } x B \text {. alpestris. }\end{array}$ & Not confirmed. \\
\hline
\end{tabular}




\section{Conclusions and further work}

Regarding identification of Betula, the following should be kept in mind:

1. Always make use of as many identification features as possible when making a determination (Table 1). Published studies that report difficulties in distinguishing $B$. pendula and $B$. pubescens restrict consideration to a limited range of parameters, particularly quantitative measures of leaf shape. Additional discriminatory identification features should always be used.

2. Not every example of $B$. pendula / pubescens can be reliably identified, but most can as long as a suite of identification features can be assessed.

3. The $\mathrm{F} 1$ hybrid between $B$. pendula and $B$. pubescens, $B . x$ aurata cannot be reliably identified in the field. Almost all trees with a mix of characters are B. pubescens with variable evidence of introgression from $B$. pendula.

4. Variation within B. pubescens should be accepted at subspecies and / or variety level. Raising these forms to species level (Sell \& Murrell, 2018) is not supported as they are all inter-fertile tetraploids.

Unresolved issues and further fieldwork:

1. Not all small-leaved B. pubescens in Britain and Ireland are referable to var. fragrans. Trees recorded under one or other of the names associated with smallleaved B. pubescens, have been recorded from 46 vice-counties in Great Britain and Ireland. Away from the Highlands of Scotland, correspondence with BSBI vicecounty recorders indicates that very few records can, with any confidence, be assigned to var. fragrans. It is confirmed from Wales (Lake Bala) and England (Northumberland) (Ashburner \& McAllister, 2013). Irish records are unconfirmed. If some records of small-leaved $B$. pubescens are not of var. fragrans, what are they?

2. What is the distribution of var. fragrans? It is certainly the most frequent form of $B$. pubescens in many upland parts of the Scottish Highlands. It is the typical type in the Cairngorms glens, and it occurs at least as far north as Strath Naver in Sutherland. The type specimen is from the Isle of Bute (v.c.100), so it may also occur throughout the western Highlands. However not all B. pubescens in northern Scotland is var. fragrans. Trees close to the coast near Lochinver (v.c.108) are much larger leaved, and fall within subsp. pubescens.

3. Betula pubescens var. fragrans is not reported from mainland Europe. Does it occur there, or is it endemic to Great Britain (and possibly Ireland)?

4. Do examples of B. pubescens occur in Scotland that could be referred to var. pumila? As discussed above, almost certainly yes, but thought to be rare. The frequency of $\mathrm{B}$. pubescens with clear signs of introgression from $B$. nana is unknown.

5. Do discrete, identifiable forms of $B$. pubescens occur in geographically limited areas? If so, how do they maintain their separate identity?

6. What are the trees referred to as 'celtibericd in Wales? Do trees with similar appearance occur elsewhere?

7. Regarding the recording of birches. The BSBI distribution database, popular recording software, eg. MapMate and web-based recording, eg. iRecord, only give the option of using the taxon name $B$. pubescens subsp. tortuosa when recording small-leaved trees. Trees positively recorded as var. fragrans, should as a temporary, stop-gap measure be recorded using the name tortuosa, but the correct identification should be added to the Comments field. These records can then be transferred to the correct taxon as and when database dictionaries are updated. 


\section{Acknowledgements}

This paper could not have been written without Ashburner and McAllister's Betula monograph. Hugh McAllister also provided detailed comments on earlier drafts of this paper, and discussed Betula identifications over recent years. John Crossley commented on earlier drafts of this paper, shares an enthusiasm for Betula in northern Scotland and provided images for Figs. 20 and 28. Arthur Chater discussed his records of $B$. celtiberica in Wales and provided the image for Fig. 24.

\section{References}

Ashburner, K. \& McAllister, H.A. 2013. The Genus Betula. A Taxonomic Revision of Birches. Kew: Kew Publishing.

Atkinson, M.D. 1992. Biological flora of the British Isles. Betula pendula Roth ( $B$. verrucosa Ehrh.) and B. pubescens Ehrh. Journal of Ecology 80: 837-870.

Atkinson MD. \& Codling A.N. 1986. A reliable method for distinguishing between Betula pendula and B. pubescens. Watsonia 7: 5-6.

Chater, A.O. 2010a. Betula celtiberica in Wales. BSBI Welsh Bulletin 85: 17-19. Available at: https://bsbi.org/wpcontent/uploads/dlm_uploads/Welsh_Bulletin_85.pdf.

Chater, A.O. 2010b. Flora of Cardiganshire. Aberystwyth: Privately published.

Clapham, A.R., Tutin, T.G. and Warburg, E.F. 1952. Flora of the British Isles. $1^{\text {st }}$ ed. Cambridge: Cambridge University Press.

Clapham, A.R., Tutin, T.G. and Warburg, E.F. 1968. Excursion Flora of the British Is/es. $2^{\text {nd }}$ ed. Cambridge: Cambridge University Press.

Clapham, A.R., Tutin, T.G. and Moore, D.M. 1987. Flora of the British Isles. $3^{\text {rd }}$ ed. Cambridge: Cambridge University Press.

Druce, G.C. 1905. Report for 1904, p.33. The Botanical Exchange Club and Society of the British Isles.

Forbes, J.C. \& Kenworthy, J.B. 1973. Distribution of two species of birch forming stands on Deeside, Aberdeenshire. Transactions of the Botanical Society of Edinburgh 42:1: 101-110.

Gardiner, A.S. 1984. Taxonomy of infraspecific variation in Betula pubescens Ehrh., with particular reference to the Scottish Highlands. Proc. of the Royal Soc. of Edinburgh 85B: 13-26.

Gill, J.A. \& Davy, A.J. 1983. Variation and polyploidy within lowland populations of the Betula pendula / B. pubescens complex. New Phytol. 94: 433-451.

Hamet-Ahti, L. 1987. Mountain birch and mountain woodland in NW Europe. Phytocoenologia 15 (4): 449-453.

Howland, D.E., Oliver, R.P. \& Davy, A.J. 1995. Morphological and molecular variation in natural populations of Betula. New Phytol. 130: 117-124.

Jonsell, B. 2000. Betula account. In: Jonsell, B., ed. Flora Nordica, Volume 1. Stockholm: The Bergius Foundation. The Royal Swedish Academy of Sciences.

Linnaeus, C. 1745. Flora Suecica. Stockholm: Laurentius Salvius.

Linnaeus, C. 1753. Species Plantarum, vol. 2. Stockholm: Laurentius Salvius. Marshall, E.S. 1901. Plants of North Scotland, 1900. Journal of Botany 39: 270-271. Marshall, E.S. 1914. Betula account. In: Moss, C.E., The Cambridge British Flora. Volume 2. Cambridge: Cambridge University Press.

Nokes, D.C.B. 1979. Biosystematic studies of Betula pendula Roth and B. pubescens Ehrh. in Great Britain. PhD thesis. The Polytechnic, Wolverhampton. 
Orlova, N.I. 1978. O statute dvukh vidiv berez. Vestn. Leningradsk. Univ., Ser.3 Biol. Geogr. 1978-1: 56-62.

Rich, T.C.G. \& Jermy, A.C. 1998. Plant Crib 1998. London: BSBI.

Rose, F. 2006. The Wild Flower Key. London: Frederick Warne.

Sell, P. \& Murrell, G. 2018. Flora of Great Britain and Ireland. Volume 1. Cambridge: Cambridge University Press.

Stace, C.A. 1991. New Flora of the British Isles. $1^{\text {st }}$ ed. Cambridge: Cambridge University Press.

Stace, C.A. 2019. New Flora of the British Isles. $4^{\text {th }}$ ed. Middlewood Green, Suffolk: C $\&$ M Floristics.

Stace, C.A., Preston, C.D. and Pearman, D.A. 2015. Hybrid Flora of the British Isles. Bristol: BSBI.

Streeter, D. 2009. Collins Wild Flower Guide. London: Collins.

Thórsson, Æ. Th., Pálsson, S., Sigurgeirsson, A., Anamthawat-Jónsson, K. 2007. Morphological Variation among Betula nana (diploid), B. pubescens (tetraploid) and their Triploid Hybrids in Iceland. Annals of Botany 99: 1183-1193.

Vãre, H. 2001. Mountain birch taxonomy and floristics of mountain birch woodlands. In: Wielgolaski, F.E., ed. Nordic mountain birch ecosystems. Man and the biosphere series 27: 35-46. Paris and Parthenon, New York: UNESCO.

Wang, N., Borrell, J.S., Bodles, W.J.A., Kuttapitiya, A., Nichols, R.A. and Buggs, R.J.A. 2014a. Molecular footprints of the Holocene retreat of dwarf birch in Britain. Molecular Ecology 23: 2771-2782.

Wang, N., Borrell, J.S. \& Buggs, R.J.A. 2014b Is the Atkinson discriminant function a reliable method for distinguishing between Betula pendula and B. pubescens (Betulaceae)?, New Journal of Botany 4:2: 90-94.

Walters, S.M. 1964. Betula account. In: Flora Europaea, Vol. 1. Tutin, T,G., Heywood, V.A., Burges, N.A., Valentine, D.H., Walters, S.M. and Webb, D.A.. Cambridge: Cambridge University Press.

Walters, S.M. 1975. Betula, In Stace, C.A. Hybridization and the Flora of the British Isles. London: Academic Press.

Warburg, E.F. 1952. Betula account. In: Clapham, A.R., Tutin, T.G. and Warburg, E.F., Flora of the British Isles. Cambridge: Cambridge University Press.

Worrell, R. \& Malcolm, D.C. 1998. Anomalies in the distribution of silver birch (Betula pendula Roth) populations in Scotland. Botanical Journal of Scotland 50:Issue 1: $1-10$.

Zohren, J., Wang, N., Kardailsky, I., Borrell, J.S., Joecker, A., Nichols, R.A. \& Buggs, R.J.A. 2016. Unidirectional diploid-tetraploid introgression among British birch trees with shifting ranges shown by restriction site-associated markers. Molecular Ecology 25: 2413-2426.

Copyright retained by author(s). Published by BSBI under the terms of the Creative Commons Attribution 4.0 International Public License.

ISSN: $2632-4970$

https://doi.org/10.33928/bib.2021.03.099 